\title{
Hair Cell Loss, Spiral Ganglion Degeneration, and Progressive Sensorineural Hearing Loss in Mice with Targeted Deletion of Slc44a2/Ctl2
}

\author{
Pavan Kommareddi, ${ }^{1}$ Thankam Nair, ${ }^{1}$ Bala Naveen Kakaraparthi, ${ }^{1}$ Maria M. Galano, ${ }^{1}$ \\ Danielle Miller, ${ }^{1}$ Irina Laczkovich, ${ }^{1}$ Trey Thomas, ${ }^{1}$ Lillian Lu, ${ }^{1}$ Kelli Rule, ${ }^{2}$ Lisa Kabara, ${ }^{1}$ \\ Ariane Kanicki, ${ }^{1}$ Elizabeth D. Hughes, ${ }_{1}^{3}$ Julie M. Jones, ${ }^{5}$ Mark Hoenerhoff, ${ }^{2}$ Susan G. Fisher, ${ }^{6}$ \\ Richard A. Altschuler, ${ }^{1}$ David Dolan, ${ }^{1}$ David C. Kohrman, ${ }^{1,5}$ Thomas L. Saunders, ${ }^{3,4}$ and \\ ThOMAS E. CAREY ${ }^{1}$ \\ ${ }^{1}$ Kresge Hearing Research Institute, Department of Otolaryngology/Head and Neck Surgery, University of Michigan, 1150 West \\ Medical Center Drive, 5311 Medical Science I, Ann Arbor, MI 48109-5616, USA \\ ${ }^{2}$ Unit for Laboratory Animal Medicine, University of Michigan, Ann Arbor, MI 48109, USA \\ ${ }^{3}$ Department of Internal Medicine, Division of Molecular Medicine and Genetics, University of Michigan, Ann Arbor, MI \\ 48109, USA \\ ${ }^{4}$ Biomedical Research Core Facilities, Transgenic Animal Model Core, University of Michigan, Ann Arbor, MI 48109, USA \\ ${ }^{5}$ Department of Human Genetics, University of Michigan, Ann Arbor, MI 48109, USA \\ ${ }^{6}$ Department of Clinical Sciences and Temple Clinical Research Institute, Temple University School of Medicine, Philadelphia, \\ PA, USA
}

Received: 9 April 2015; Accepted: 1 October 2015; Online publication: 13 October 2015

\begin{abstract}
SLC44A2 (solute carrier 44a2), also known as CTL2 (choline transporter-like protein 2), is expressed in many supporting cell types in the cochlea and is implicated in hair cell survival and antibody-induced hearing loss. In mice with the mixed C57BL/6-129 background, homozygous deletion of Slc44a2 exons 3-10 $\left(\operatorname{Slc} 44 a 2^{\Delta / \Delta}\right)$ resulted in high-frequency hearing loss and hair cell death. To reduce effects associated with age-related hearing loss (ARHL) in these strains, mice carrying the $\bar{S} l c 44 a 2^{\Delta^{-}}$allele were backcrossed to the ARHL-resistant $\mathrm{FVB} / \mathrm{NJ}$ strain and evaluated after backcross seven
\end{abstract}

Pavan Kommareddi and Thankam Nair contributed equally to this work.

Correspondence to: Thomas E. Carey - Kresge Hearing Research Institute, Department of Otolaryngology/Head and Neck Surgery · University of Michigan - 1150 West Medical Center Drive, 5311 Medical Science I, Ann Arbor, MI 48109-5616, USA. Telephone: 734-764-4371; email: careyte@umich.edu
(N7) (99\% FVB). Slc $44 a 2^{\Delta / \Delta}$ mice produced abnormally spliced Slc44a2 transcripts that contain a frameshift and premature stop codons. Neither full-length SLC44A2 nor a putative truncated protein could be detected in $S l c 44 a 2^{\Delta / \Delta}$ mice, suggesting a likely null allele. Auditory brain stem responses (ABRs) of mice carrying the $S l c 44 a 2^{\Delta}$ allele on an FVB/NJ genetic background were tested longitudinally between the ages of 2 and 10 months. By 6 months of age, $\operatorname{Slc} 44 a 2^{\Delta / \Delta}$ mice exhibited hearing loss at $32 \mathrm{kHz}$, but at 12 and $24 \mathrm{kHz}$ had sound thresholds similar to those of wild-type $S l c 44 a 2^{+/+}$and heterozygous +/ $\operatorname{Slc} 44 a 2^{\Delta}$ mice. After 6 months of age, Slc $44 a 2^{\Delta / \Delta}$ mutants exhibited progressive hearing loss at all frequencies and $+/ \operatorname{Slc} 44 a 2^{\Delta}$ mice exhibited moderate threshold elevations at high frequency. Histologic evaluation of $\operatorname{Slc} 44 a 2^{\Delta / \Delta}$ mice revealed extensive hair cell and spiral ganglion cell loss, especially in the basal turn of the cochlea. We conclude that Slc44a2 function is required for long-term hair cell survival and maintenance of hearing. 
Keywords: choline transporter-like protein 2, solute carrier protein $44 \mathrm{a} 2$, supporting cells, auditory brain stem responses, hair cell loss, spiral ganglion cell loss, murine gene knockout

\section{INTRODUCTION}

SLC44A2 (solute carrier 44a2) is a transmembrane glycoprotein (Nair et al. 2004) that belongs to the solute carrier family of osmolyte transporters involved in transmembrane transport of small molecules (He et al. 2009). It is highly expressed in inner ear supporting cells and was discovered as the target of a monoclonal antibody, KHRI-3 (Zajic et al. 1991). In vivo administration of KHRI-3 resulted in hearing loss in mice and guinea pigs, thereby implicating this protein in antibody-mediated hearing loss (Nair et al. 1995, 1997, 1999). SLC44A2 is also strongly expressed in supporting cells in the human inner ear and is involved in autoimmune hearing loss in humans (Disher et al. 1997; Zeitoun et al. 2005; Kommareddi et al. 2009). Since antibody to SLC44A2 adversely affects hair cell survival and hearing, we postulated that this protein must be essential for normal function of the inner ear. To study its role in hearing, we created targeted knockout mice that carried a deletion of exons 3-10 of the Slc44a2 gene. Initial studies of the effects of this deletion on a C57BL/6 genetic background revealed hair cell loss and hearing loss, but were hampered by the age-related hearing loss (ARHL) associated with the $\bar{C} d h \overline{3}^{753 A}$ variant carried by C57BL/6J (Noben-Trauth et al. 2003). We backcrossed the Slc44a2 deletion onto the FVB/NJ strain, which carries the ARHL-resistant $C d h 23^{753 G}$ or wild-type allele. Here, we demonstrate that the Slc44a2 deletion on a majority FVB background results in early-onset hearing loss, particularly at high frequency. The hearing loss is progressive and is associated with extensive hair cell and spiral ganglion cell loss. Thus, this study indicates a critical role of Slc44a2 in the maintenance of auditory function.

\section{METHODS}

Targeting Vector Construction and Targeted Disruption of the Slc44a2 Gene in Embryonic Stem Cells

$129 / \mathrm{SvJ}$ mouse strain genomic DNA was obtained from the Jackson Laboratory (Bar Harbor, ME). Three pairs of primers (Table 1) were used to amplify the Slc44a2 targeted region (exons 3-10) (Fig. 1A) and the $5^{\prime}$ and $3^{\prime}$ homology arms on either side of these exons. The $5^{\prime}$ homologous (5' HA) arm spans $3.1 \mathrm{~kb}$ of the distal end of intron 2; the 1.9-kb targeted deletion site (TDS) includes exons $3-10$; and the $3^{\prime}$ homologous arm ( $\left.3^{\prime} \mathrm{HA}\right)$ spans the $2.7-\mathrm{kb}$ proximal region of intron 10. The PCR products were cloned into pGEM-T vectors, and wild-type sequences were verified by the University of Michigan DNA Sequencing Core. Standard molecular cloning techniques were used to insert the Slc44a2 fragments into the pLoxPFlpNeo vector (Hiraoka et al. 2006). This vector contains the neomycin resistance gene (PGKneo cassette) between FRT recombination sites for antibiotic selection after transfection of the targeting construct into mouse embryonic stem (ES) cells. The final targeting construct contained the TDS between the loxP recombination sites, the $5^{\prime}$ HA preceding the $5^{\prime}$ FRT site and the $3^{\prime}$ HA following the $3^{\prime}$ loxP site (Fig. 1B).

The targeting vector was linearized with SacII and electroporated into R1 agouti mouse ES cells (129X1/ SvJx129S1/SvJ) (Nagy et al. 1993). Electroporation and antibiotic selection of mouse ES cells were performed at the University of Michigan Transgenic Animal Model Core (Hughes and Saunders 2011). Genomic DNA prepared from $n e o^{R}$ ES cell clones was analyzed for homologous recombination of the targeting construct by long-range genomic PCR (Expand Long Kit-Roche, Indianapolis, IN) with two primer sets (Table 2): GGGGGCAGGGAGGG CTAAATCT (forward, Hour F ( $\underline{\text { Homologous up- }}$ stream region Forward)) located upstream of the $5^{\prime}$ HA and GCETTACGGGTGGATGTGGAATGTG (reverse, Hour R) derived from the PGKneo cassette, and with control primers for the wild-type Slc44a2 gene: GCACCGAAGGAATGGGGAAGGAT (nHourF (normal HourF)) located upstream of the $5^{\prime} \mathrm{HA}$ and CATCTCGCCAGCCCCAGGTCATAC (PosR-nHourF (Positive control reverse primer for $\mathrm{nHourF})$ ) located near the distal end of the 5' HA (Fig. 1B).

\section{Confirmation of Recombinant Clones Using Southern Blot}

A 411-bp hybridization probe (probe 1) was amplified from genomic DNA sequences located upstream of the $5^{\prime} \mathrm{HA}$, gel purified, doubly radiolabelled with ${ }^{32} \mathrm{P}-$ dCTP plus ${ }^{32}$ P-dATP (Perkin Elmer, Waltham, MA) using the Prime-Gene Labeling System (Promega, Madison, WI), and separated from unincorporated nucleotides by centrifugation through a Sephadex column. Ten micrograms of genomic DNA from PCRpositive ES clones was digested overnight with HindIII in the presence of $4 \mathrm{mM}$ spermidine. Restriction fragments were separated by electrophoresis on $0.8 \%$ agarose gels with $1 \times \mathrm{TBE}$ buffer and transferred to Zetaprobe GT filters (Bio-Rad Labs, Hercules, CA). The radiolabeled probe was prehybridized with $50 \mu \mathrm{g}$ mouse Cot-1 DNA (Life Technologies, Invitrogen, 


\section{TABLE 1}

Primers used for cloning the targeting region

\begin{tabular}{llll}
\hline $5^{\prime} \mathrm{KO} \mathrm{F}$ & TTCCTTGCTCTGCTTTGTAAGTCC & $5^{\prime} \mathrm{KO} \mathrm{R}$ & CTGTTCATTTTGAAAACTTT- \\
Ex KO F & AGACCAGACCTGGTGGCACAG & Ex KO R & GGTAGCAGACATTTGGCACTT \\
$3^{\prime} \mathrm{KO} \mathrm{F}$ & CCGGGACCGCTTTCAGAA & $3^{\prime} \mathrm{KO} \mathrm{R}$ & GACATTAGGTAAACATCTTCA \\
\hline
\end{tabular}

5' KO F and 5' KO R amplify the 5' homologous region; Ex-KO F and Ex KO R amplify the exon 3-10 targeted deletion site; and 3' KO F and 3' KO R amplify the 3' homologous region

Grand Island, NY) at $65^{\circ} \mathrm{C} 30 \mathrm{~min}$ before adding the probe to the filters. Hybridization with the radiolabeled probe was carried out in $0.5 \mathrm{M}$ sodium phosphate and $7 \% \mathrm{SDS}, \mathrm{pH} 7.2$, at $65{ }^{\circ} \mathrm{C}$ overnight. Filters were washed at $65^{\circ} \mathrm{C}$ for $15 \mathrm{~min}$ twice in the following solutions containing $0.1 \% \mathrm{SDS}$ : $2 \times \mathrm{SSC}, 1 \times$ SSC, $0.2 \times$ SSC, and $0.1 \times$ SSC. Biomax-MS film (Kodak) was exposed to filters with an intensifying screen at $-80{ }^{\circ} \mathrm{C}$ for 2 days (Meisler et al. 2013).

Sequencing of ES Cell Clone 29, Subcloning, Selection, and Blastocyst Injection and Implantation

DNA was isolated from 1500 neoR colonies of electroporated ES cells and examined for proper insertion of the construct. PCR analysis determined a single clone (clone 29) was positive for correct homologous recombination. The construct from positive clone 29 was completely sequenced to ensure an intact insertion. The full set of sequencing primers is given in Table 2. Clone 29 was found to be heterogeneous and was subcloned; 50 subclones were rescreened by genotyping (primers in Table 3). PCRpositive subclones with normal karyotypes were selected for blastocyst injection and implantation in pseudopregnant mice. Male progeny (ES cell-mouse chimeras) were selected based on high coat color contribution and genotyping results and were bred to wild-type C57BL/ 6 mice to generate N1 offspring. N1 germ line founders carrying the $S l c 44 a 2^{\text {neo }}$ allele $\left(B 6 ; 129 S v-S l c 44 a 2^{t m 1 T e c}\right)$ were crossed with pCAGGsFLP mice (Kranz et al. 2010). The resulting N2 Slc44a flox mice $\left(B 6 ; 129 S v-S l c 44 a 2^{\text {tm1.1Tec }}\right)$ were then crossed with B6.FVB-Tg(EIIa-Cre) mice carrying a Cre recombinase gene on the adenovirus EIIa promoter (Cat Number 003724) (Jackson Labs, Bar Harbor, $\mathrm{ME})$ to delete Slc44a2 exons 3-10 and generate the mutant Slc44a2 $2^{\Delta}$ allele $\left(B 6 ; 129 S v-S l c 44 a 2^{\text {tm } 1.2 T e c}\right)$.

\section{DNA/RNA Extraction, Genotyping, RT-PCR, and Sequencing}

To obtain genomic DNA, mouse tail tip biopsies were each digested overnight at $55{ }^{\circ} \mathrm{C}$ in $1 \mathrm{ml}$ of tail solubilization buffer (TSB) (Miller et al. 1988) containing $45 \mu \mathrm{l}(>27 \mathrm{AU})$ proteinase K (Qiagen,
Valencia, CA; cat 19131) activated at $37^{\circ} \mathrm{C}$. TSB as modified here consisted of $100 \mathrm{mM}$ Tris- $\mathrm{HCl} \mathrm{pH} 8.5$, $5 \mathrm{mM}$ EDTA, $0.2 \%$ SDS, and $200 \mathrm{mM} \mathrm{NaCl}$. After digestion, the samples were cooled and $400 \mu \mathrm{l}$ of chilled tail salts $(4.21 \mathrm{M} \mathrm{NaCl}, 0.63 \mathrm{M} \mathrm{KCl}$, and $10 \mathrm{mM}$ Tris ( $\mathrm{pH} 8.0)$ ) was added to precipitate the proteins and SDS. The samples were vigorously mixed and incubated for $1 \mathrm{~h}$ at $4{ }^{\circ} \mathrm{C}$. Insoluble material was removed by centrifugation and genomic DNA was precipitated from the supernatant by the addition of two volumes of cold $100 \%$ ethanol, and centrifugation. After washing the pellet, the extracted DNA was dissolved in $150 \mu \mathrm{l}$ TE buffer (Invitrogen, Grand Island, NY) and then PCR-genotyped. Both Expand Long Template PCR and GC Rich kits (Roche Diagnostics, Indianapolis, IN) were used with Hour primers (Table 2). Genotyping primers used to assess deletion of the neo-cassette and the exons 3-10 are listed in Table 3. Cochlea (one to two ears), lung, and kidney tissues $(\sim 30 \mathrm{mg})$ were homogenized using a 1.5-ml disposable pellet/pestle tube or a polytron homogenizer, and RNA was isolated using RNeasy mini kit or a Trizol/chloroform method (Qiagen, Valencia, CA). Reverse transcription PCR (RT-PCR) was performed (Kommareddi et al. 2010), and complementary DNA (cDNA) was prepared from total RNA isolated from homozygous knockout FVB (lung) and C57BL/ 6 (kidney) tissues; these were analyzed for Slc44a2 expression and submitted for Sanger sequencing using the primers shown in Table 4.

\section{Backcrossing to the FVB Strain}

B6;129Sv-+/Slc44a2 ${ }^{\Delta}$ mice carrying the targeted allele were backcrossed to FVB/NJ mice for seven generations (N7) to generate a line (FVB.129SvSlc44a2 $2^{\text {tm1.2Tec }}$ ) with $99 \%$ FVB genetic background on average. Intercrosses were carried out at N7 to assess hearing loss in F1 wild-type $(+/+)$, heterozygous $\left(+/ S l c 44 a 2^{\Delta}\right)$, and homozygous mutant $\left(\operatorname{Slc} 44 a 2^{\Delta / \Delta}\right)$ progeny. Heterozygous progeny mice were intercrossed to maintain the strain. Representative mice from this N7-F1 group were used for immunohistochemistry and morphometric analysis, auditory brain stem response (ABR) testing, spiral ganglion cell counts, and necropsy. 
A

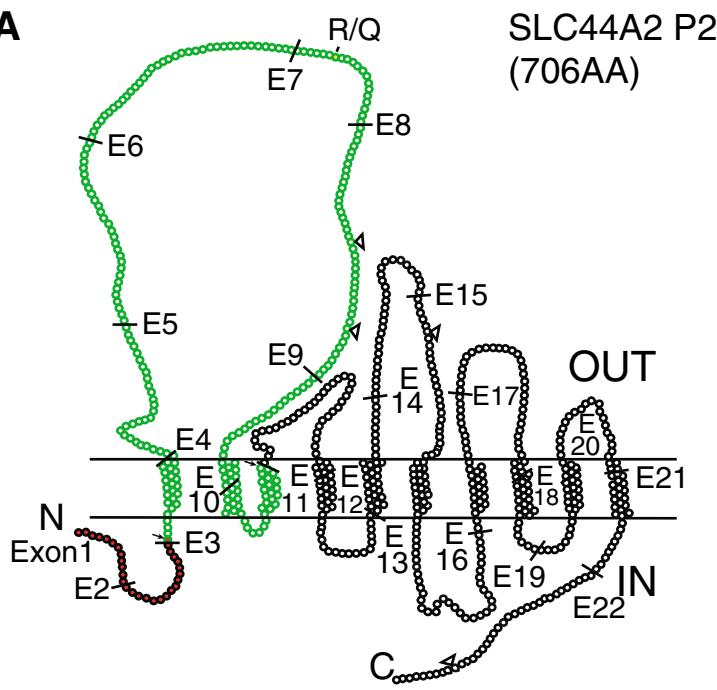

B

Slc44a2 Knockout Mouse Experimental Plan

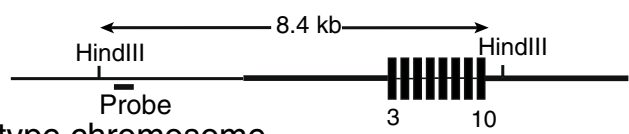

Wild-type chromosome

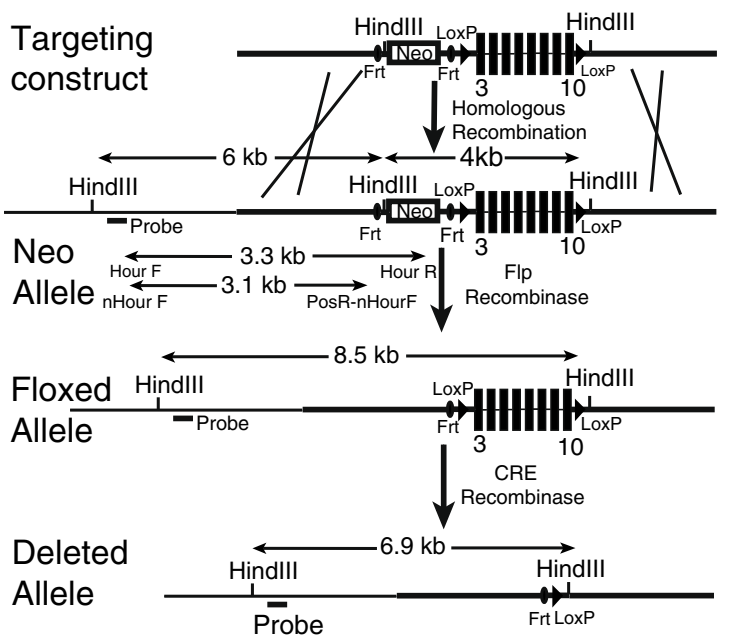

FIG. 1. A The predicted topology of the SLC44A2 isoform P2 protein. Each ball represents an individual amino acid. The region targeted for deletion in the knockout is shown in green. The amino acids colored red are included in the first 29 amino acids encoded by a truncated and aberrantly spliced S/c44a2 mRNA produced in the knockout mouse. Small arrows at E3 and E11 point to the sites where the aberrant transcript is spliced, leading to an out-of-frame transcript that is terminated by two stop codons in exon 14. Open triangles indicate locations of predicted $\mathrm{N}$-linked glycosylation sites. $R / Q$ indicates the codon 152 (isoform P1)/154 (isoform P2) arginine/ glutamine polymorphism. B Experimental design of the S/c44a2 gene-knockout mouse. Exons 3-10 of the mouse Slc44a2 gene were chosen for deletion. The targeting construct was created with a $5^{\prime}$ homology region followed by a neo-cassette flanked by FRT sites, loxP sites flanking exons 3-10, and finally, the 3' homology region. Mice carrying the targeting construct in the correct location were mated with FLP recombinase-expressing mice to remove the neocassette, and their offspring were mated to Cre recombinaseexpressing mice to delete $S / C 44 a 2$ exons 3-10.
Immunohistochemistry and Morphometric Analysis

Cochleae from FVB N7-F1 +/+, +/Slc44a2 $2^{\Delta}$, and Slc $44 a 2^{\Delta / \Delta}$ mutant mice were processed for wholemount immunohistochemistry and morphometric analysis. Immunohistochemistry was done using antimyosin 7A (hair cells) and rhodamine phalloidin (actin) using published protocols (Sha et al. 2008). Expression of Slc44a2 in the transgenic mice was carried out using affinity-purified rabbit anti-CTL2-NT as described previously (Beyer et al. 2011). Inner ear cross sections were generated in the KHRI Core Histology Facility and evaluated. Photographs were taken using both light and confocal microscopy. Hair cell counts were completed from surface preparations as described (Sha et al. 2008). The cytocochleogramobtained data was compared to a database of normal $\mathrm{CBA} / \mathrm{J}$ mouse cochlea, and missing hair cell percentages were calculated for each row and plotted as a function of the distance from the apical to the basal end of the surface preparation.

\section{Auditory Brain Stem Response Testing and Analysis}

ABR testing (Sha et al. 2008) was carried out at 12, 24, and $32 \mathrm{kHz}$ at different time points. Mixed models were generated to examine differences in hearing thresholds among the three genotype groups while accounting for age, frequency, and repeated measures on the same mice. Comparisons focused on relating FVB N7-F1 +/Slc44a $2^{\Delta}$ and Slc44a $2^{\Delta / \Delta}$ mice to $+/+$ mice. Kaplan-Meier curves were also produced to demonstrate the time to development of threshold $>50 \mathrm{~dB}$ sound pressure level (SPL) by genotype. A $50-$ dB SPL was selected since it represents the start of moderate hearing loss. Statistical significance was defined as $p<0.05$. Mixed model and Kaplan-Meier analyses were performed using Stata 13.1 (StataCorp, 2013 StataCorp, College Station, TX).

\section{Spiral Ganglion Cell Counts and Analysis}

Counts of spiral ganglion cell (SGC) bodies in apical, middle, and basal turns from FVB N7-F1 mice were performed using published methodology (Sha et al. 2008). Raw counts and spiral ganglion cell density (cells $/ 10,000 \mu^{2}$ ) were determined and then analyzed. A generalized linear model (GLM) examined the role of cochlear location (apex, middle, base) and genotype (i.e., $+/+,+/ \operatorname{Slc} 44 a 2^{\Delta}, \operatorname{Slc} 44 a 2^{\Delta / \Delta}$ ) as a correlate of SGC density. Statistical significance was defined as $p<0.05$. The Tukey-Kramer method was used to adjust $p$ values for multiple pairwise compar- 
TABLE 2

Sequencing the rCTL2 insert from clone 29 (E29/plate)

\begin{tabular}{|c|c|c|c|}
\hline Hour F & GGGGGCAGGGAGGGCTAAATCT & Hour R & GCСТACCGGTGGATGTGGAATGTG \\
\hline nHour F & GCACCGAAGGAATGGGGAAGGAT & PosR-nHourF & CATCTCGCCAGCCCCAGGTCATAC \\
\hline $5^{\prime} \mathrm{HOF}$ & CCCAAAGATCCAAAACAGTCCACA & $5^{\prime} \mathrm{HO} \mathrm{R}$ & GCCCGGGCTACATTGAGAGTC \\
\hline $5^{\prime} \mathrm{HO} \mathrm{F1}$ & TTTATGTCTGTGGTCTGCGTTGTG & $5^{\prime} \mathrm{HO} \mathrm{R} 1$ & CAGCCAAACСТTATCTCСAGTCСТ \\
\hline Lox $\mathrm{P}$ scrn $\mathrm{F}$ & GGCAGGACAGCAAGGGGGAGGAT & Lox $\mathrm{P}$ scrn $\mathrm{R}$ & ACGGGGCTCTGGGTCTCAAAGTT \\
\hline Ex KO F & GGGCGAATTCTGTGGGCAAAAG & Ex KO R & AGGGGAAGAGGTGAAACGCATTAC \\
\hline $3^{\prime} \mathrm{KO} \mathrm{F}$ & CCGGGACCGCTTTCAGAA & $3^{\prime} \mathrm{KO} \mathrm{R}$ & GACATTAGGTAAACATCTTCA \\
\hline 3' $\mathrm{HO} \mathrm{R}$ & GCCGGGGCTACATTGAGAAACT & $3^{\prime} \mathrm{HO} \mathrm{R} 1$ & GTAGAGCCGCAAACGCAGACAGTA \\
\hline $3^{\prime} \mathrm{KO}-3^{\prime} \mathrm{HO} \mathrm{F} 1$ & GCAGGTCGAGGGACCTAATAAC & $3^{\prime} \mathrm{KO}-3^{\prime} \mathrm{HO}$ R1 & GGTGTTAGCAGGCCTGGAGAAATG \\
\hline $3^{\prime} \mathrm{HOF} 2$ & TCAGTTCCAGCTTTCAGTTTCCTT & $3^{\prime} \mathrm{HO}$ R2 & AGCCACAACCATAGCACCTCACTG \\
\hline $3^{\prime} \mathrm{HOF}$ & GGTCTGCCCCCTTCGTTTTACA & $3^{\prime} \mathrm{HO}$ R3 & ACGGGGCTCTGGGTCTCAAAGTT \\
\hline $3^{\prime} \mathrm{HO} \mathrm{F} 4$ & GGCCGTCTGAGCTTGATGTCTGTC & $3^{\prime} \mathrm{HO}$ R4 & AATTATGCACAGGAGGCTTAGTCA \\
\hline 3' HO F7 & CCTGGCTTTTCTGTATTCTGATGC & & \\
\hline $3^{\prime} \mathrm{HOF}$ & GGCGACTTGATATTTGTTTTTGAT & & \\
\hline 3' HO F5 & CCTGGATGGCTTTTAGTGAGTTGC & & \\
\hline
\end{tabular}

isons. GLM and post hoc comparisons were performed using SAS 9.4 (SAS Institute, 2014, Cary, NC).

\section{Full Phenotype Analysis (Necropsy)}

FVB N7-F1 mice were analyzed for whole-body histopathology in the Unit for Laboratory Animal Medicine, Pathology Service. Animals were euthanized humanely using $\mathrm{CO}_{2}$, and euthanasia was confirmed with thoracotomy. Full necropsies were performed on animals in the Unit for Laboratory Medicine Pathology sections by MH. This evaluation included complete blood counts and assessments of brain, heart, lung, liver, kidney, spleen, mesenteric lymph node, thymus, eye, skin, skeletal muscle, stomach, duodenum, jejunum, ileum, colon, rectum, and reproductive tract, which were collected in $10 \%$ neutral buffered formalin (NBF) for routine histopathology examination. The tympanic bullae were opened with a 22-gauge needle and placed in $10 \%$ NBF for $48 \mathrm{~h}$. The heads were then sectioned at the posterior aspect of the eyes to remove the rostral

TABLE 3

Primers used for genotyping

\begin{tabular}{ll}
\hline Primer name & Sequence \\
\hline NeoGenoF2 & TGA TGC TCT TCG TCC AGA TCA TCC \\
NeoGeno R1 & TGA ACA AGA TGG ATT GCA CGC AGG \\
NeoDelFn2 & GGACTCGGTGCCCTTCTGGA \\
NeoDelRn2 & TGGCTGGCCTAAAACCTGCTATG \\
Exon D F1 & GGGGATGCGGTGGGCTCTAT \\
Exon D R1 & AGCCACAACCATAGCACCTCACTG \\
ExonD F2 & TCATGTGAGTTGGAAGGAAAGTGG \\
ExonD R2 & AGTCACTGGGCTAAAGAGATGTC \\
ExonD F & GGGGATGCGGTGGGCTCTAT \\
ExonD R & TTGGTCGGTTAAACAGTGGAGAA \\
NeoExoD F & TTTGCCTGGTGAATGCTGAGAGTA \\
NeoExoD R & TTGGTCGGTTAAACAGTGGAGAA \\
\hline
\end{tabular}

portion of the skull, and sectioned along the midline. The soft tissue around the tympanic bullae was dissected away, and specimens were placed in Immunocal (Decal Corporation, Tallman, NY) for $24 \mathrm{~h}$ for decalcification. Specimens were embedded in paraffin and sectioned routinely for histopathology.

\section{Immunoprecipitation and Western Blot}

CTL2-NT antibody raised in rabbits immunized with an SCL44A2 unique but phylogenetically conserved antigenic peptide encoded by exon 2 in the N-terminal portion of SLC44A2 was used for immunoprecipitation and Western blot analysis of SLC44A2 in lung and kidney extracts prepared as described previously (Nair et al. 2004; Kommareddi et al. 2009, 2010).

\section{RESULTS}

\section{Generation of a Targeted Deletion of Slc $44 a 2$}

The Slc44a2/Ctl2 gene has 22 exons encoding 706 amino acids. Exons 3-10 encode the first and largest extracellular loop of the protein (Nair et al. 2004) shown in green in Figure 1A. The KHRI-3 antibody that induces hearing loss in mice and guinea pigs (Nair et al. 1995, 1997) targets an N-linked carbohydrate moiety of the SLC44A2 protein (Kommareddi et al. 2010). Two of the consensus N-linked glycosylation sites (shown as open triangles, Fig. 1A) are located on the first outer loop (Nair et al. 2004; Kommareddi et al. 2010). Based on the logic that this large protein loop is important to the normal function of the protein, exons 3-10 were chosen for deletion in ES cells using a targeting vector (Fig. 1B). Correct targeting in ES cell clones was verified by PCR and Southern blot analysis. One ES cell clone, number 29, was targeted correctly. This clone was subcloned and 
TABLE 4

Primers used for Slc44a2 full-length cDNA sequencing of wild-type and knockout mice

\begin{tabular}{ll}
\hline Mouse-specific full-length primers for isoforms P1 and P2 & \\
MsP1 CTL2/SLC44A2 F & TCGCGCTGGCTTCGGACTCA \\
MsP1 CTL2/SLC44A2 R & GCACAGGGCTGGGCATA CAAG \\
MsP2 CTL2/SLC44A2 F & GCGGGTGGCGGCTGTGTC \\
MsP2 CTL2/SLC44A2 R & GGATGGCCAAAGTAGGGGTGAGG \\
Sequencing primers & \\
Forward primers & Location and name \\
1. ATGGGACGCCTCAGAAATACGA & Ms AK041533 90-111 bp MsCTL2F1 \\
2. ACACTCGCGACTTTGACTATTACA & Ms AK041533 438-461 bp MsCTL2F2 \\
3. GCGATTCCTGGCTGGCATTAT & Ms AK041533 814-834 bp MsCTL2F3 \\
4. CCCCTTGCGGAATGAGAGC & Ms AK041533 1294-1312 bp MsCTL2F4 \\
5. GGTACCACACGGGCTCCTTAG & Ms AK041533 1551-1571 bp MsCTL2F5 \\
6. ATTGTGGGTAGTGTGGGCATCC & Ms AK041533 1880-1901 bp MsCTL2F6 \\
Reverse primers & Location and name \\
1. AGAAGCTTGCTGCAGACATCCTA & Ms AK041533 2472-2494 bp MsCTL2R1 \\
2. GTCAGGATCGGAACCCAGTAATAA & Ms AK041533 1963-1986 bp MsCTL2R2 \\
3. GCCCGTGTGGTACCTGAGTGCT & AK041533 1543-1564 bp MsCTL2R3 \\
4. CCCTGCTGGCTTCTTTGATG & Ms AK041533 1093-1112 bp MsCTL2R4 \\
5. AAAGGTTTGCTGGGGGTGATA & Ms AK041533 538-558 bp MsCTL2R5 \\
6. CAGGGGGTTGGCACACTTCA & Ms AK041533 278-297 bp MsCTL2R5
\end{tabular}

progeny clones were PCR tested for the 3.3-kb recombined insert containing the neo-cassette (Figs. 1B and 2A). Incorrectly targeted clones showed no 3.3-kb band (clone 78) and wild-type cells $(+/+$ ) had only the $3.1-\mathrm{kb}$ band. The murine Slc44a2 gene has two HindIII sites, one upstream of the $5^{\prime}$ homologous region and the other in the $3^{\prime}$ homologous region, which span $8.4 \mathrm{~kb}$ in length in the wildtype mouse. After recombination, a new HindIII site in the vector located after the $5^{\prime}$ FRT site (Fig. 1B) was expected to produce a $6.0-\mathrm{kb} 5^{\prime}$ fragment in HindIIIdigested DNA of correctly targeted clones. Southern blot analysis demonstrated that this $6.0-\mathrm{kb}$ fragment (as well as the wild-type 8.4 -kb fragment) was recognized by the probe in five PCR-positive subclones (Fig. 2B).

The five correctly targeted ES subclones (Fig. 2A, B) were sequenced and verified to contain the complete Slc44a2 recombinant gene. Three clones exhibiting normal karyotypes were injected into blastocysts and implanted in pseudopregnant female mice. ES cell-mouse chimeras were bred to $\mathrm{C} 57 \mathrm{BL} / 6$ mice. Germ line transmission of the transgene from all three clones was detected in genomic DNA of resulting $\mathrm{N} 1$ offspring using primer sets that amplify across the neo-cassette and exons 3-10. Transgenepositive mice were crossed with $\mathrm{C} 57 \mathrm{BL} / 6$ mice carrying FLP recombinase (Kranz et al. 2010), resulting in progeny mice $\left(\mathrm{NeO}^{\Delta} \mathrm{Slc} 44 \mathrm{a} 2^{\text {flox }}\right)$ with successful removal of the neo-cassette (Fig. 3A, B). Neodeleted $S l c 44 a 2^{f l o x} /+$ mice were intercrossed to obtain progeny that were $+/+,+/ S l c 44 a 2^{\text {flox }}$, and Slc44a2 flox $/$

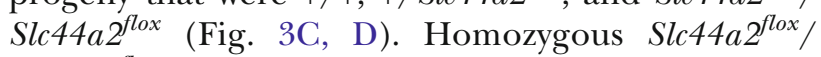
Slc44a2 $2^{\text {flox }}$ mice were crossed with $\mathrm{C} 57 \mathrm{BL} / 6$ mice carrying Cre recombinase to produce the mutant
Slc $44 a 2^{\Delta}$ allele with deletion of exons 3-10. The + / $S l c 44 a 2^{\Delta}$ mice were then crossed and the progeny
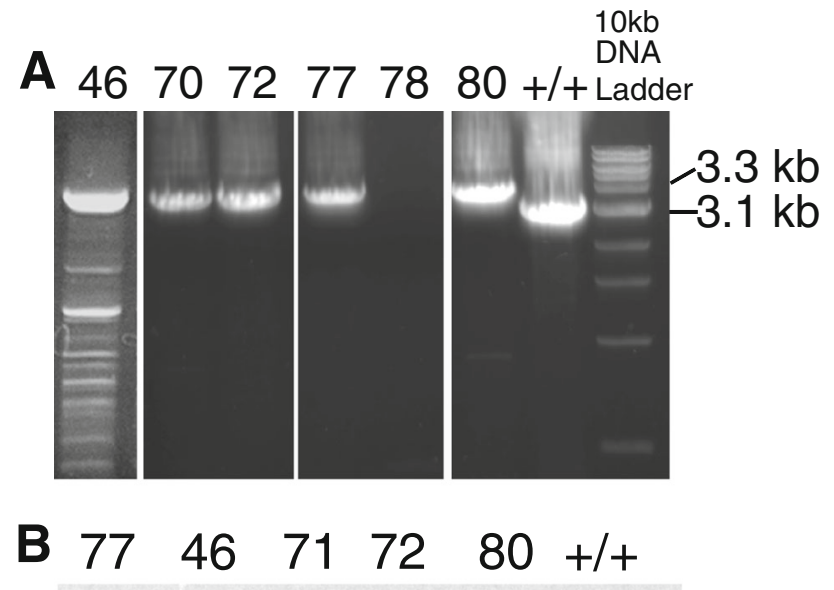

$8.4 \mathrm{~kb}$ $6.0 \mathrm{~kb}$

FIG. 2. PCR and Southern blot results for five positive ES cell subclones. A PCR genotyping of DNA from the five positive ES cell subclones carrying the Slc44a2 targeting construct $(3.3-\mathrm{kb}$ PCR product), subclone 78 that lacked the targeting construct, and +/+ (wild-type) mouse DNA (3.1-kb PCR product) without the construct. B Southern blot showing the presence of the S/c44a2 8.4-kb wildtype and the $6.0-\mathrm{kb}$ recombinant construct in the five positive subclones of clone 29. 


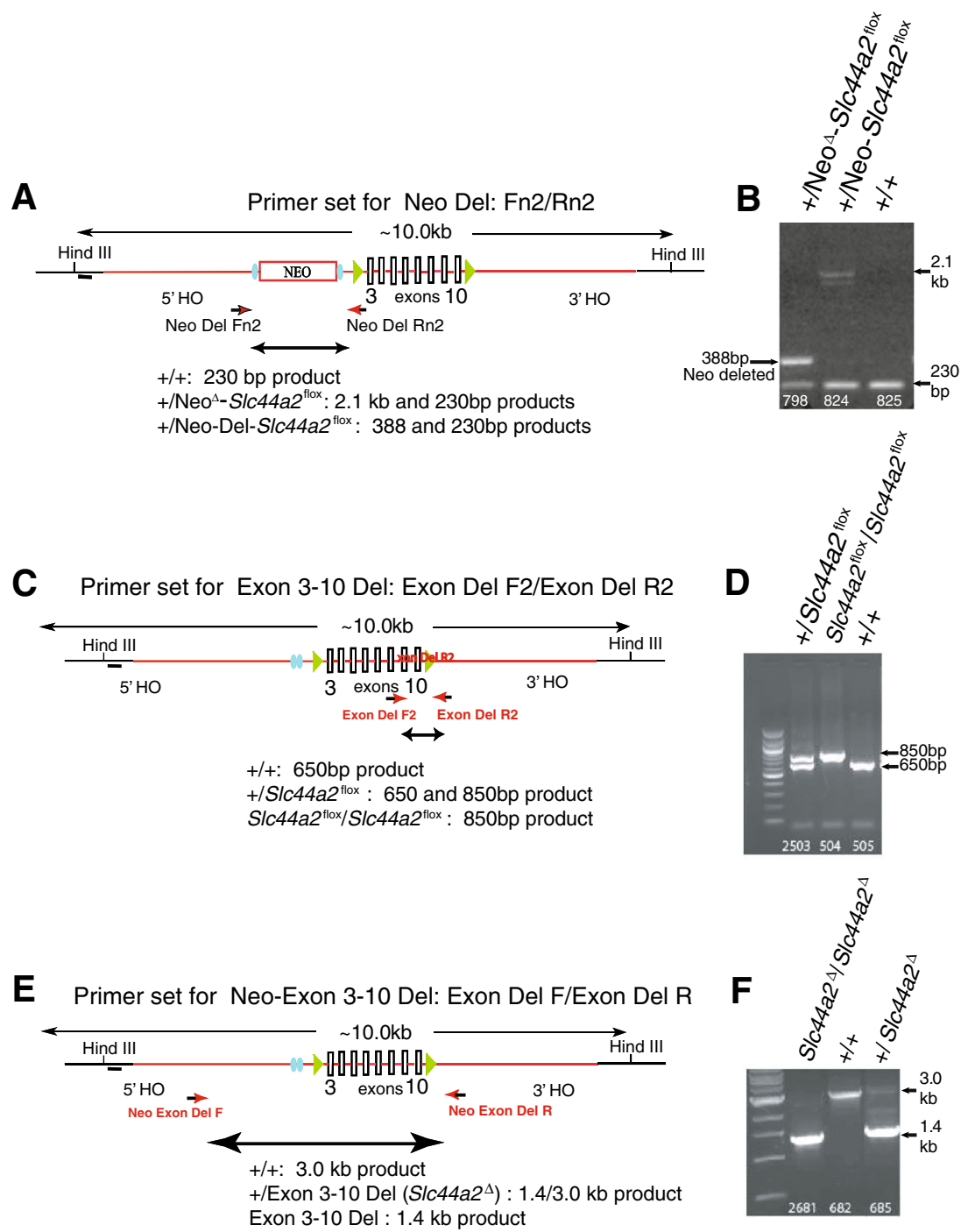

FIG. 3. Deletion schema in transgenic mice showing the primer sets and PCR results used to demonstrate successful deletion of the neo-cassette and S/c44a2 exons 3-10. A, B PCR results for heterozygous +/neo-deleted floxed S/C44a2, +/Neo-S/C44A2, and a wild-type animal $+/+$ without the construct. C, D PCR results for

were found to have the expected distribution of $+/+$, $+/ \operatorname{Slc} 44 a 2^{\Delta}$, and Slc44a2 $2^{\Delta / \Delta}$ genotypes (Fig. 3E, F).

\section{Mutant Slc44a2 $2^{\Delta / \Delta}$ Mice on the C57BL/6 Back- ground}

Slc $44 a 2^{\Delta / \Delta}$ mice appeared healthy and fertile and did not exhibit circling or head tilting behavior. No visible size difference or other atypical observations were noted upon necropsy between normal and knockout mice except for changes in the inner ear described below. RT-PCR of RNA from lung and kidney tissue of $+/+,+/ S l c 44 a 2^{\Delta}$, and Slc44a2 ${ }^{\Delta / \Delta}$ mice (C57BL/6 background) was conducted to detect the expression of Slc44a2 isoforms P1 and P2 (P1, using the upstream exon $1 \mathrm{a}$, and $\mathrm{P} 2$, using the more proximal exon $1 \mathrm{~b}$ ) correct location of floxed exons 3-10 in heterozygous $+/ S / C 44 a 2^{\text {flox }}$ and homozygous $S / c 44 a 2^{\text {flox }} / S / c 44 a 2^{\text {flox }}$, as well as $+/+$ mice. $\mathbf{E}, \mathbf{F}$ PCR results for homozygous $S / C 44 a 2^{\Delta} / S / C 44 a 2^{\Delta}$, heterozygous +/ $S / C 44 a 2^{\Delta}$, and +/+ mice after crossing to $\mathrm{C} 57 \mathrm{BL} / 6$ carrying Cre.

(Kommareddi et al. 2010). Full-length transcripts $(3.3 \mathrm{~kb})$ of both isoforms were expressed in $+/+$ mice. Both isoforms of the 3.3-kb full-length transcripts and both isoforms of the deleted $2.5-\mathrm{kb} S l c 44 A 2^{\Delta}$ transcript (lacking exons 3-10) were expressed in the +/ Slc $44 a 2^{\Delta}$ animals. As expected in Slc $44 a 2^{\Delta / \Delta}$ mutants, only the $2.5-\mathrm{kb} S l c 44 A 2^{\Delta}$ transcripts of the P1 and P2 isoforms were observed (Fig. 4A). Similarly, after transfer of the deleted allele to the FVB strain (Fig. 4B), the wild-type 3.3-kb transcript was produced in $+/+$ mice, but only the deleted $2.5-\mathrm{kb}$ transcript could be amplified in cDNA from the lung and cochlea of the $+/ S l c 44 a 2^{\Delta}$ and $S l c 44 a 2^{\Delta / \Delta}$ mice (Fig. 4B).

Immunoprecipitation of the Slc44a2 protein from lung and kidney tissue of $+/+,+/ \operatorname{Slc} 44 a 2^{\Delta}$, and 


\section{A RT- PCR of Slc44a2 variants}

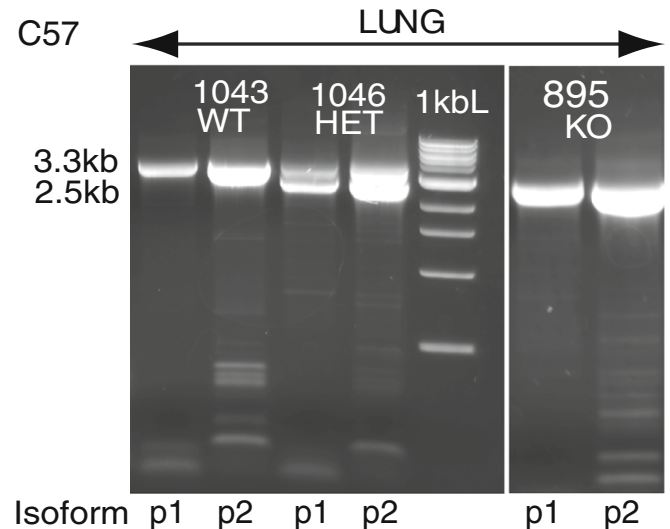

Genotype +/+ +/SIc44a2 ${ }^{\Delta} \quad S^{\prime c 44 a 2^{\Delta / \Delta}}$
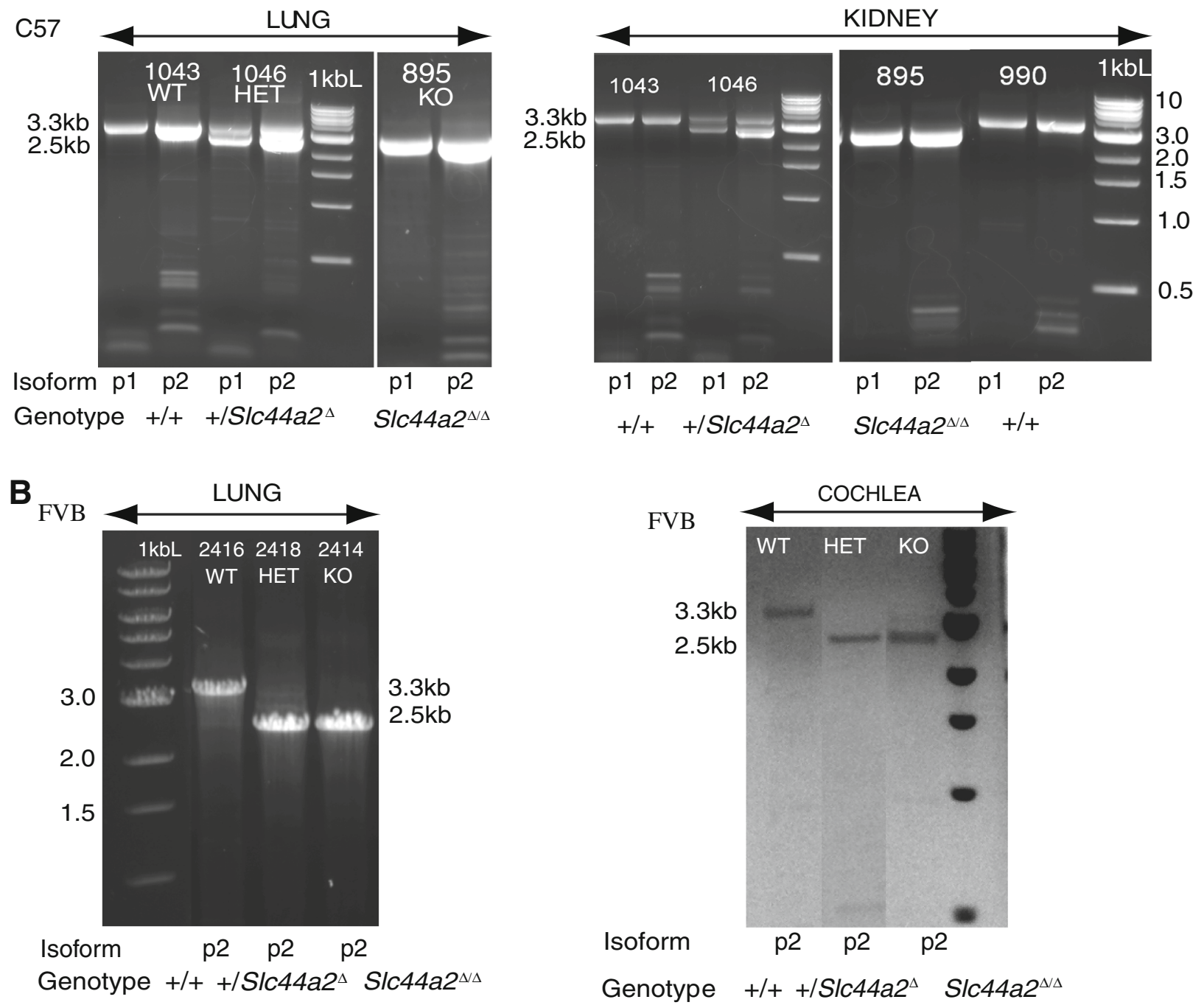

C

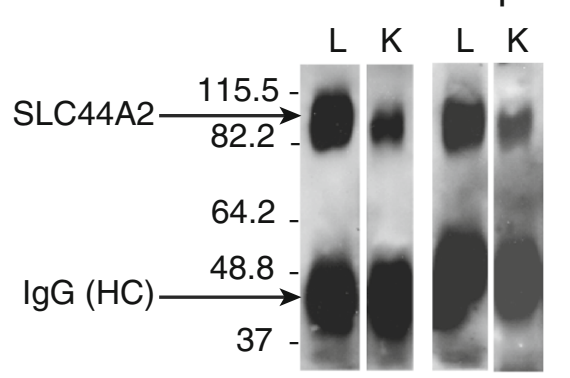

Immunoprecipitation/Western Blot- rabbit anti-SIc44a2-NT
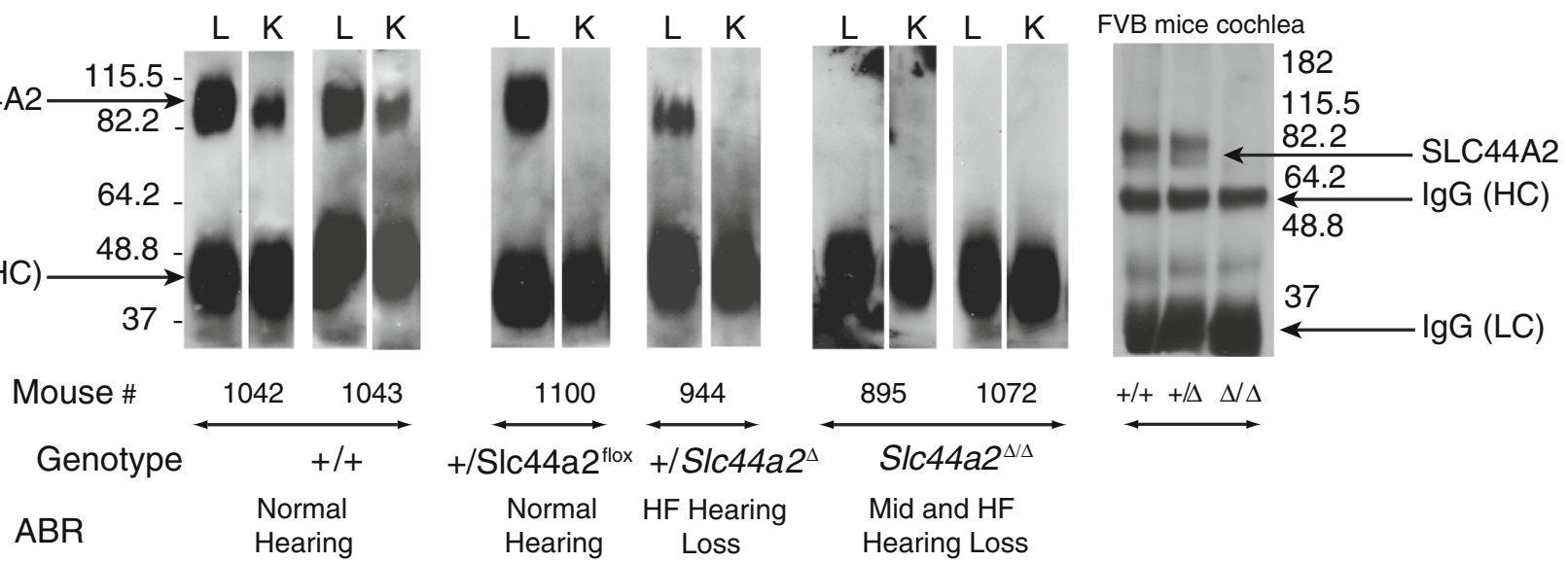
FIG. 4. Expression of Slc44a2 message and protein in wild-type and knockout mice. A RT-PCR using lung and kidney mRNA in the $\mathrm{C} 57 \mathrm{BL} / 6$ strain. The figure demonstrates expression of the mRNA for both the P1 and P2 Slc44a2 isoforms. Wild-type mouse 1043 and 990 (left and right panels) expressed the full-length 3.3-kb cDNA; heterozygous mouse $1046\left(+/ S / c 44 a 2^{\Delta}\right)$ (center panels) expressed both the full-length $3.3-\mathrm{kb}$ and the truncated $2.5-\mathrm{kb}$ message; and homozygous knockout mouse $895\left(S / c 44 a 2^{\Delta / \Delta}\right)$ (right panels) expressed only the truncated 2.5-kb message. In lung, the P2 isoform is more abundant than P1; however, in kidney, they are equally expressed. B RT-PCR showing expression of the Slc44a2 P2 isoform in lung and cochlea in WT, $+/+, \mathrm{HET},+/ S / C 44 a 2^{\Delta}$, and $\mathrm{KO} \mathrm{S/C44a2^{ \Delta / }}$ ${ }^{\Delta}$ FVB mice. In FVB mice, the overall expression of the Slc44a2 message is less strong than that in the C57 strain. In FVB heterozygous mice lung and cochlea, the full-length wild-type message was not detected due to competition by the shorter deleted transcript. To make the PCR product in FVB cochlear extract more visible, the photograph of the gel was reversed to black on white. $\mathbf{C}$ Immunoprecipitation and Western blot results using rabbit antiSLC44A2-NT. Slc44a2 expression is shown in lung and kidney samples of $\mathrm{C} 57 \mathrm{BL} / 6+/+,+/ S / C 44 a 2^{\text {flox }},+/ S / C 44 a 2^{\Delta}$, and S/C $44 a 2^{\Delta / \Delta}$ littermates with different genotypes. Mice 1042 and $1043(+/+)$ strongly express Slc44a2 in lung $(L)$ and to a lesser extent in kidney $(K)$ and have normal hearing. Slc44a2 is expressed in the lung of heterozygous mouse 1100 carrying one wild-type allele and one recombinant allele $\left(+/ S / c 44 a 2^{\text {flox }}\right.$, exons 3-10 not yet deleted), but expression is below the limit of detection in kidney tissue. Mouse 1100 has normal hearing. Heterozygous mouse $944\left(+/ S / C 44 a 2^{\Delta}\right.$, neo; exons 3-10 deleted) has low expression of Slc44a2 in lung and below detectable levels in kidney. This mouse has hearing loss at high frequency-65-dB SPL threshold at $48 \mathrm{kHz}$. Homozygous knockout mice 895 and $1072\left(S / C 44 a 2^{\Delta / \Delta}\right.$ ) have no Slc44a2 expression in lung or kidney. Mouse 895 has 50- and 70-dB SPL thresholds at 24 and $48 \mathrm{kHz}$. Mouse $1072 \mathrm{had}$ a $65-\mathrm{dB}$ SPL threshold at $48 \mathrm{kHz}$. Repeated tests using $12 \%$ gels to detect the 150-amino acid SLC44A2 ${ }^{\Delta / \Delta}$ fusion protein encoded by the alternate transcript showed no expression of the 17-kDa protein (not shown). Analysis of protein extracts of cochlea from FVB mice from all three genotypes show the same results as in $\mathrm{C} 57 \mathrm{BL} / 6$ mice with protein expression in wild-type and heterozygous mice but not in knockout mouse (right panel). Note that the protein is expressed in the $+/ \mathrm{Slc}_{\mathrm{C}} 4 \mathrm{a} 2^{\Delta}$ mice even though the message was competed for by the deleted message in the RT-PCR shown in Figure 4B.

Slc $44 a 2^{\Delta / \Delta}$ mice was performed using a rabbit SLC44A2-NT antiserum. (This antiserum, formerly called CTL2-NT, for the N-terminal CTL2 domain, was raised to the peptide encoded by exon 2 (Nair et al. 2004; Kommareddi et al. 2009).) The immunoprecipitated proteins were separated by gel electrophoresis and Western blot analysis was performed using the SLC44A2-NT antiserum. The fulllength SLC44A2 protein was prominent in lung and to a lesser extent in kidney tissue from $+/+$ mice. Heterozygous $+/ S l c 44 a 2^{\Delta}$ mice and heterozygous mice carrying the recombinant $+/$ SLC44A2 $2^{\text {flox }}$ allele (neo-deleted but exons 3-10 intact) exhibited reduced protein expression in lung and undetectable protein in kidney. Since the kidney expresses much lower levels of SLC44A2 than lung (Kommareddi et al. 2010), the absence of one allele apparently was sufficient to reduce expression in kidney to below detectable levels. No protein was expressed in the

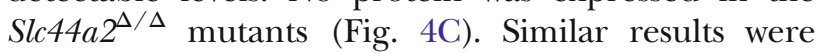
observed in protein extracts from the cochlea of FVB mice after the transfer of the deleted allele to this strain (Fig. 4C, right panel). Note that the wild-type protein band in cochlear extracts of the FVB +/ $S l c 44 a 2^{\Delta}$ mice is expressed. The RT-PCR failed to detect the wild-type cDNA in the heterozygous mice (Fig. 4B) due to relatively low transcript expression and PCR competition by the shorter deleted transcript.

Sequencing of the 2.5-kb transcript $\operatorname{Slc} 44 a 2^{\Delta / \Delta}$ mice revealed splicing from exon 2 into exon 11 (Fig. 5A, B). The open reading frame of this mutant transcript matched the wild-type Slc44a2 transcript from exon 1 through exon 2 including the first amino acid encoded by exon 3 . However, a single nucleotide frameshift within exon 11 resulted in an alternative reading frame that lacked similarity to Slc44a2 or any known protein (Fig. 5B). The reading frame was terminated by a stop codon within exon 14. The putative truncated protein, if stable, is predicted to be 150 amino acids in length $(17 \mathrm{kDa})$, with the first 29 amino acids identical to intact Slc44a2 (red text, Fig. 5B). Multiple attempts to detect the predicted truncated protein on $12 \%$ gels to insure visualization of low-mw proteins failed to detect the fusion protein in either $\operatorname{Slc} 44 a 2^{\Delta / \Delta}$ or $+/ S l c 44 a 2^{\Delta}$ mice (data not shown), indicating that the fusion protein is either not made or is unstable.

\section{A $S / c 44 a 2^{\Delta}$ alternate reading frame}

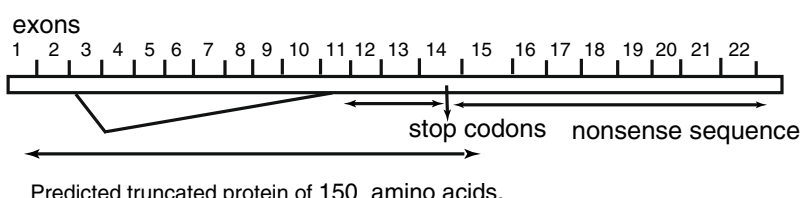

\section{B Alternate reading frame sequence}

MGKDSQNYYGKHGTPQKYDPTFKGPIYNRHLPLLHGVLETPWRGRLRRLPGGPWLPDGPPSVPALEADLDGFYDHFKHPGSGHHPVTYLSAQKDIDRHRPHQRSQQGCGTCHVLPALPTGDLLPLVSLHCLLGQHFCIPVHLQHRRVQGC.

FIG. 5. A Structure of the deleted $S / C 44 a 2$ gene. The open reading frame of this mutant transcript matched the wild-type Slc44a2 transcript through exon 2 and the first amino acid of exon 3, but exhibited a frameshift in exon 11 that encoded alternative residues until a stop codon within exon 14. B Putative 150-amino acid truncated protein deduced from the RT-PCR expressed message. The first 29 amino acids shown in red are identical to the sequence encoded by exons $1-2$ and the first amino acid of exon 3 . The open reading frame is spliced into exon 11 out-of-frame resulting in an alternate transcript (in black) that fails to match to any known proteins. If the protein was produced and stable, it would have a molecular mass of $17 \mathrm{kDa}$. As the $\mathrm{N}$-terminal amino acids are conserved in the fusion transcript, immunoprecipitation and detection with the $\mathrm{N}$-terminal antibody should detect the fusion protein if it is produced and stable. 
Mutant Slc44a2 $2^{\Delta / \Delta}$ Mice Exhibit High-

Frequency Hearing Loss, Loss of Hair Cells, and Spiral Ganglion Degeneration

At 3 months of age, ABR analysis of $S l c 44 a 2^{\Delta / \Delta}$ mice on the C57BL/6J genetic background revealed poor hearing thresholds of 65-90 dB SPL at $48 \mathrm{kHz}$ and 50-70 dB SPL at $24 \mathrm{kHz}$ associated with outer hair cell losses in the basal turns of the cochlea (data not shown). In contrast, the $+/+$ and $+/ S l c 44 a 2^{\Delta}$ mice exhibited thresholds of 20-30 dB SPL at these frequencies and relatively low levels of hair cell loss in the basal turn (data not shown). C57BL/6 mice carry the $C d h 23^{753 A}$ allele at the $A h l$ locus that is associated with ARHL (Noben-Trauth et al. 2003). To avoid the additional effects of this allele on hearing, we backcrossed Slc $44 a 2^{\Delta}$ mice to the FVB/ $\mathrm{NJ}$ strain, which carries the wild-type $C d h 23^{753 G}$ allele associated with lower sound thresholds in later life (Noben-Trauth et al. 2003). N2 backcross mice carrying the Slc $44 a 2^{\Delta}$ allele and homozygous for the FVB $C d h 23^{753 G}$ wild-type allele were used as breeders for subsequent FVB backcrosses leading to the N7 generation. At backcross generation N7 (99 \% FVB genetic background), heterozygous $+/ \operatorname{Slc} 44 a 2^{\Delta}$ mice were intercrossed to produce F1 wild-type, heterozygous, and knockout animals at the Slc44a2 locus. Knockout Slc $44 a 2^{\Delta / \Delta}$ mice in the FVB/NJ background were generally smaller than their wild-type littermates but were otherwise healthy and fertile (data not shown). Anatomic pathology review of systems by one of us (MH) found no abnormalities of any organ system (other than the inner ear), including lung and kidney which strongly express Slc44a2.

Fifty-nine F1 intercross progeny from $\mathrm{FVB} / \mathrm{NJ}$ backcross generation N7 $\left(20+/+, 19+/ S l c 44 a 2^{\Delta}\right.$, and 20 Slc $44 a 2^{\Delta / \Delta}$ ) were tested for hearing using ABR analysis in response to 12,24 , and $32 \mathrm{kHz}$ pure tone stimuli. In Figure 6A, average hearing thresholds calculated from repeated measures of the same mice as they aged from 2 to more than 8 months are shown for the $+/+$ and $\Delta / \Delta$ groups. In Slc $44 a 2^{\Delta / \Delta}$ mutants, hearing loss at $32 \mathrm{kHz}$ developed early and became notably progressive at all frequencies with age. At all three frequencies, the hearing thresholds, adjusted for age, were significantly worse in the $\operatorname{Slc} 44 a 2^{\Delta / \Delta}$ mutants than in either the $+/+$ or $+/ \operatorname{Slc} 44 a 2^{\Delta}$ mice $(p<0.0001)$. Heterozygous $+/ \operatorname{Slc} 44 a 2^{\Delta}$ mice exhibited progressive hearing loss at $32 \mathrm{kHz}$ from 4 to $>8$ months of age (not shown). In contrast, $+/+$ (all frequencies) and $+/ S \operatorname{Slc} 44 a 2^{\Delta}$ mice (12 and $24 \mathrm{kHz})$ exhibited minimal threshold shifts with aging $(\leq 15 \mathrm{~dB})$. At $24 \mathrm{kHz}$, changes in threshold after age adjustment were not significantly different between + / + and $+/ \operatorname{Slc} 44 a 2^{\Delta}$ mice ( $p$ values $>0.3$ ). A full model, which included all variables, further demonstrated

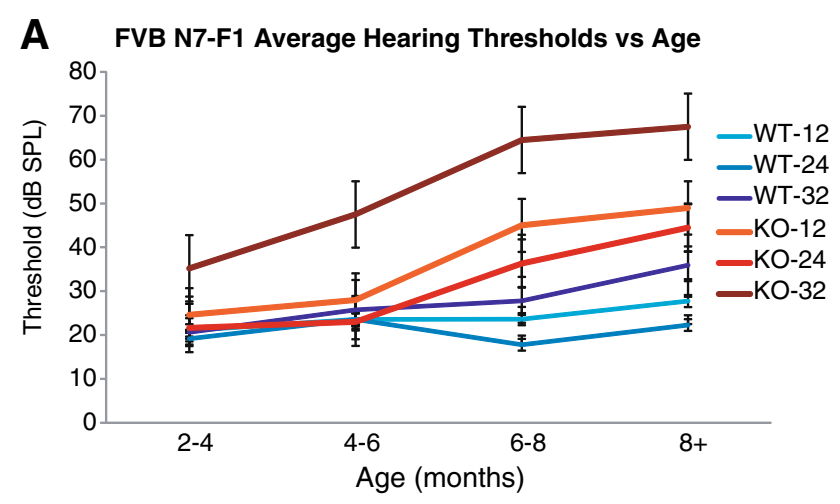

B

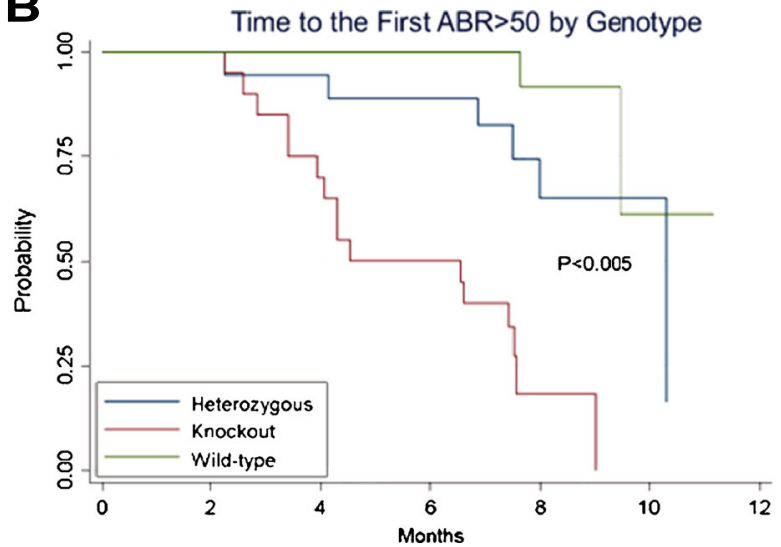

FIG. 6. $S / c 44 a 2^{\Delta / \Delta}$ mice on the FVB background exhibit progressive hearing loss. A Mice carrying the wild-type $(W T,+/+)$ and the homozygous knockout $\left(K O, S / C 44 a 2^{\Delta / \Delta}\right) S / C 44 a 2$ alleles on an FVB/ NJ background (N7-F1) were evaluated longitudinally for hearing at 2-4 months of age to 8 or more months. ABRs to pure tone stimuli at 12,24 , and $32 \mathrm{kHz}$ were measured periodically on the mice as they aged. Each pure tone frequency is indicated by a different shade of color (12 kHz-light, $24 \mathrm{kHz}$-medium, $32 \mathrm{kHz}$-dark). Mean threshold responses are indicated for WT (b/ue) and KO (red) mice; error bars represent standard deviation. $N=20$ for WT and $n=20$ for $\mathrm{KO}$, but some were studied histologically during the course of the follow-up, resulting in different numbers of mice at the later time points. At all frequencies, WT mice maintained relatively normal hearing over time with threshold means between 20 and 25 dB SPL. Mutant KO mice demonstrated progressive hearing loss at all frequencies. Slc44a2 loss has the greatest effect at high frequency, whereas hearing loss was milder at 12 and 24 kHz. B Kaplan-Meier curve presenting the likelihood of an animal from each genotype group first developing a hearing threshold above $50 \mathrm{~dB}$ SPL (moderate hearing loss). This curve accounts for all three testing frequencies $(12,24$, and $32 \mathrm{kHz})$. Each line shows the probability of mice in each group *not* yet having a threshold greater than $50 \mathrm{~dB}$ SPL. The curves decline over time, as the probability for first developing a threshold $>50 \mathrm{~dB}$ SPL increases with age.

that $\mathrm{ABR}$ results in $+/+$ and $+/ \operatorname{Slc} 44 a 2^{\Delta}$ mice did not significantly differ $(p$ values $>0.17$ ) after adjustment for age and frequency. Kaplan-Meier curves demonstrate time to development of first threshold $>50 \mathrm{~dB}$ SPL by genotype (Fig. 6B). We used $50 \mathrm{~dB}$ SPL since this represents moderate hearing loss and there were not enough mice who reached the $>80$-dB SPL level to warrant analyses. Figure $6 \mathrm{~B}$ shows the results regard- 
less of testing frequency and demonstrates significantly increased and faster development of hearing loss with age among the knockout mice compared to the wild-type and heterozygous groups $(p=0.005)$.

Histologic examination of the inner ear was carried out on a randomly selected subset of these 59 mice $(N=25)$ after their final ABR to correlate hearing status with cochlear morphology. Surface preparations of the organ of Corti were evaluated for hair cell survival. Representative images from organ of Corti surface preparations and cytocochleograms from FVB

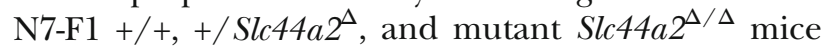
are shown in Figure 7 , together with the ABR recordings for these three mice (Fig. 8). By 8 months of age, the high hearing thresholds observed in Slc $44 a 2^{\Delta / \Delta}$ mutants across all measured frequencies are associated with relatively high levels of loss of both inner and outer hair cells throughout the cochlea. With the exception of the extreme base and apex of the cochlea, hair cell loss at 8-9 months is relatively minimal in $+/+$ and $+/ \operatorname{Slc} 44 a 2^{\Delta}$ mice, which exhibit lower sound thresholds. The opposite ear of each of the representative animals was decalcified, fixed, and sectioned to examine the organ of Corti and the spiral ganglion in mid-modiolar sections (Fig. 9). The midmodiolar sections through the organ of Corti were consistent with the surface preparation data. The organ of Corti has a normal appearance in all three turns of the $+/+$ mouse. The apex and middle turns of the mouse exhibited near-normal appearance of the organ of Corti, but in the basal turn, the outer hair cells were missing. Visible stereocilia can be seen in some sections corresponding to both inner and outer hair cells in the $+/+$ and $+/ S \operatorname{Slc} 44 a 2^{\Delta}$ mice. The Slc $44 a 2^{\Delta / \Delta}$ mouse organ of Corti has a near-normal appearance in the apex and middle turns, but in the basal turn, the morphology is abnormal with absence of the tunnel of Corti and no distinguishable hair cells (Fig. 9A). These observations bear similarity to the results in Figure 7. Further examination of the midmodiolar sections also revealed gross abnormalities of the spiral ganglion cells in the basal turn of the +/ Slc44a2 $2^{\Delta}$ mouse and the $\Delta / \Delta$ mouse. Multiple midmodiolar sections from $5+/+, 4+/ \operatorname{Slc} 44 a 2^{\Delta}$, and 7 Slc $44 a 2^{\Delta / \Delta}$ mice were examined for spiral ganglion cell density as previously described (Sha et al. 2008). The results are depicted graphically in Figure 10. The basal segment of the spiral ganglion of the $+/ \operatorname{Slc} 44 a 2^{\Delta}$ and Slc $44 a 2^{\Delta / \Delta}$ animals displayed extensive loss of cells although severity varied from animal to animal. In contrast, spiral ganglion cells were intact in the $+/+$ mice (Fig. 9B). A generalized linear model that examined both cochlear location $(p=0.0026)$ and genotype $(p<0.0001)$ revealed that these two are independently and significantly associated with spiral ganglion cell density (Table 5). SGC density is different between the base and middle turns ( $p=0.0017)$; the differences between the base and apex $(p=0.1080)$ and middle and apex $(p=0.2456)$ are not statistically significant. When comparing density across genotypes, there is a statistically significant difference between $+/+$ and $+/ \operatorname{Slc} 44 a 2^{\Delta} \quad(p=0.0114)$ and $+/+$ and Slc44a2 $2^{\Delta / \Delta}(p<0.0001)$. The difference between heterozygous and knockout mice approaches significance $(p=0.0834)$ (Table 5).

Inner ear surface preparations from other $++/,+$ / $S l c 44 a 2^{\Delta}$, and mutant $S l c 44 a 2^{\Delta / \Delta}$ mice were also stained by indirect immunofluorescence with affinitypurified rabbit anti-Slc44a2 (CTL2-NT) as shown in Figure 11. Note that the expected expression of Slc44a2 on supporting cells is present in $+/+$ (Fig. 11A), less so in $+/{\text { slc } 44 a 2^{\Delta}}$ (Fig. 11B, C), and completely absent from Slc44a2 $2^{\Delta / \Delta}$ ears (Fig. 11D), which is consistent with the Western blots shown in Figure 4C.

\section{DISCUSSION}

A full understanding of the roles of supporting cells in maintenance of inner ear function is only beginning (May et al. 2013; Monzack and Cunningham 2013; Wan et al. 2013). Similarly, the role of the supporting cell protein SLC44A2 in inner ear function is not well understood. SLC44A2 was discovered as the antigenic target of a monoclonal antibody (KHRI-3) raised against isolated cells from the inner ear (Zajic et al. 1991). KHRI-3 showed strong reactivity with supporting cells, but not sensory cells, and the antibody target was called the "supporting cell antigen." We demonstrated upregulation of KHRI-3 antigen in areas of hair cell loss induced by drugs or noise (Ptok et al. 1993). Subsequent studies revealed that systemic KHRI-3 antibody was capable of causing hearing loss in mice (Nair et al. 1995). Infusion of purified KHRI-3 into the guinea pig cochlea led to antibody binding to supporting cells and loss of sensory hair cells. Where hair cells were missing, KHRI-3 antibody staining intensity of adjacent supporting cells was increased (Nair et al. 1997). Additionally, potent antigen expression occurred where adjacent supporting cell membranes form scars in the space left by the dying hair cell (Nair et al. 1997). These findings strongly suggested that the KHRI-3-defined supporting cell antigen has important functions in survival of sensory cells in the cochlea, and that antibody binding to supporting cells interferes with this function leading to hair cell death. Additionally, the accumulation of the protein at the scars implies a role for SLC44A2 in maintaining the integrity of the reticular lamina of the organ of Corti. 


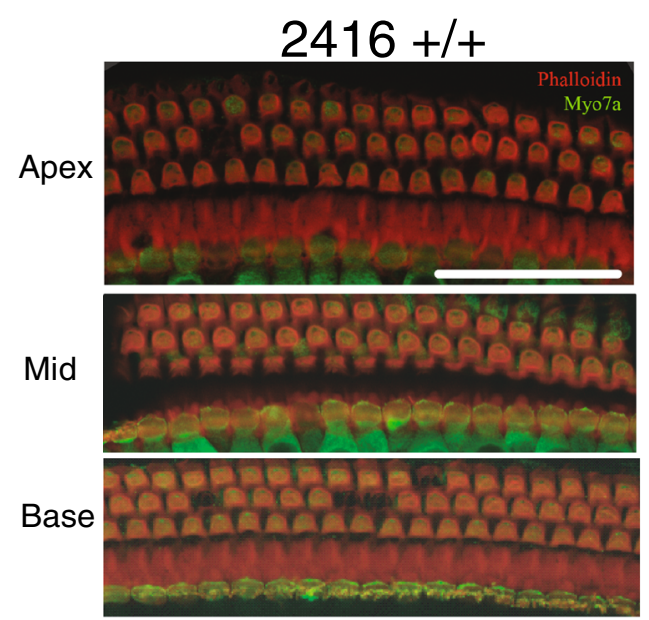

$2418+$ SIc44a2 $^{4}$

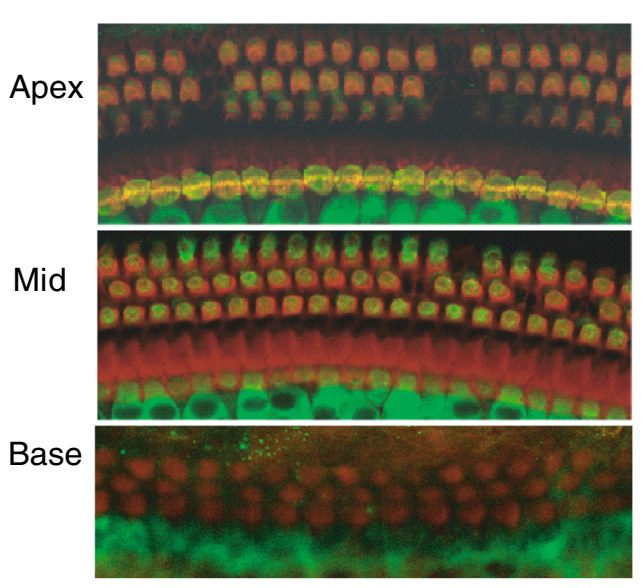

$2414 S / c 44 a 2^{\Delta \Delta}$

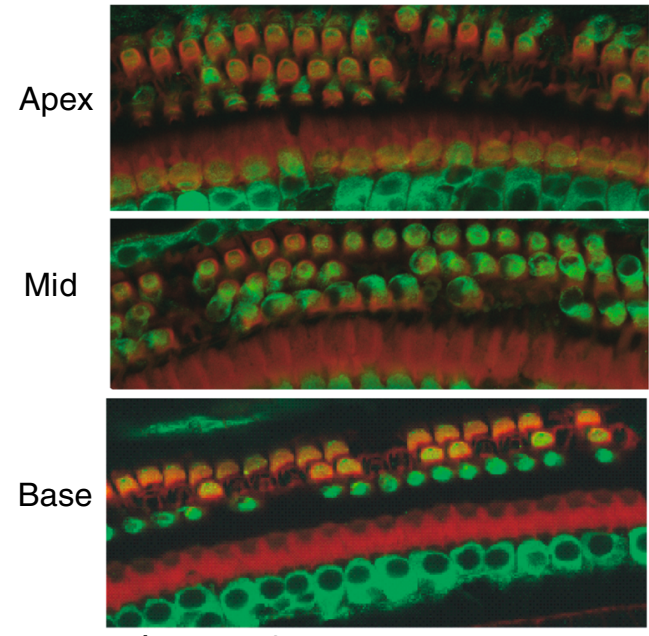

bar $=50 u m$
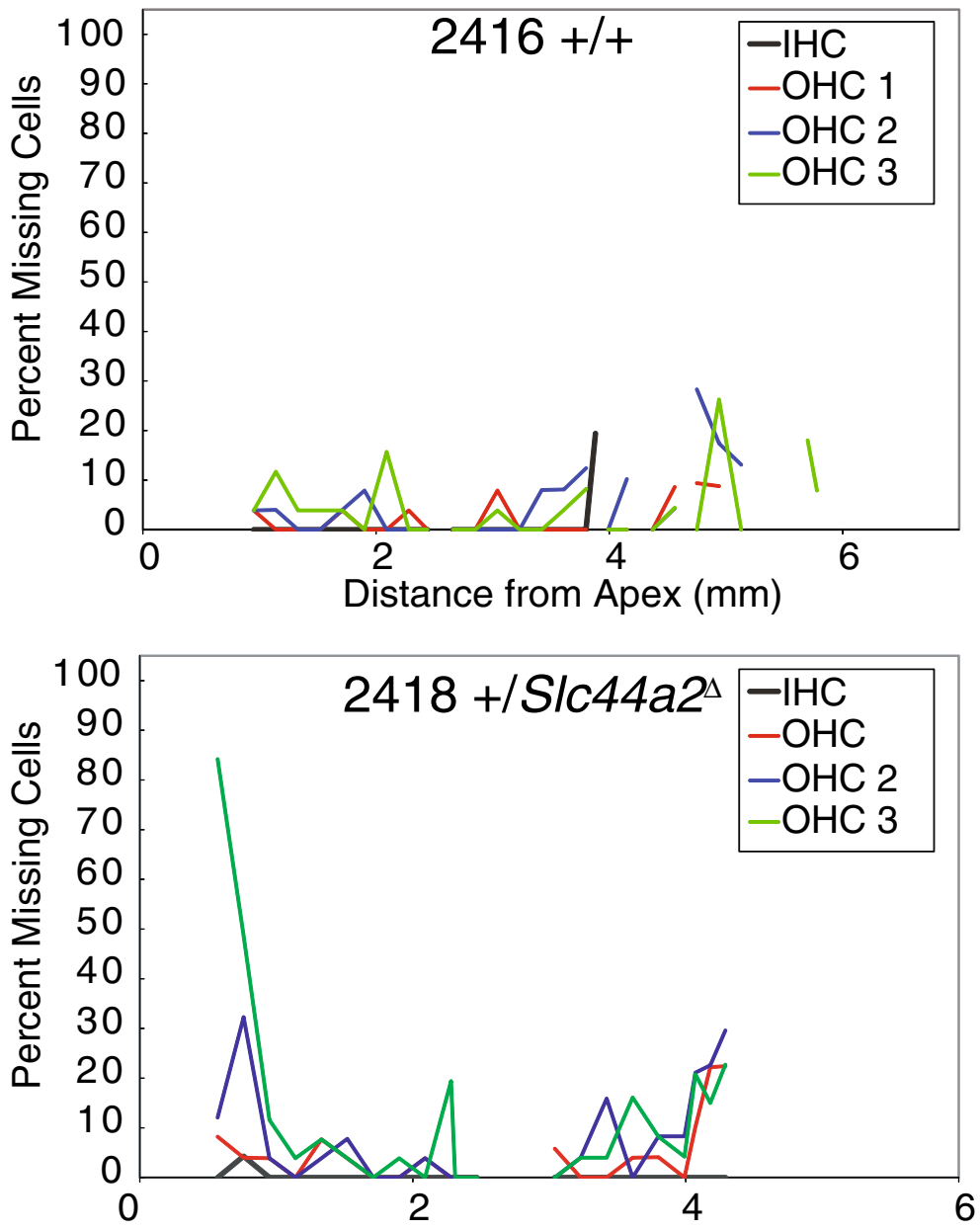

Distance from Apex (mm)

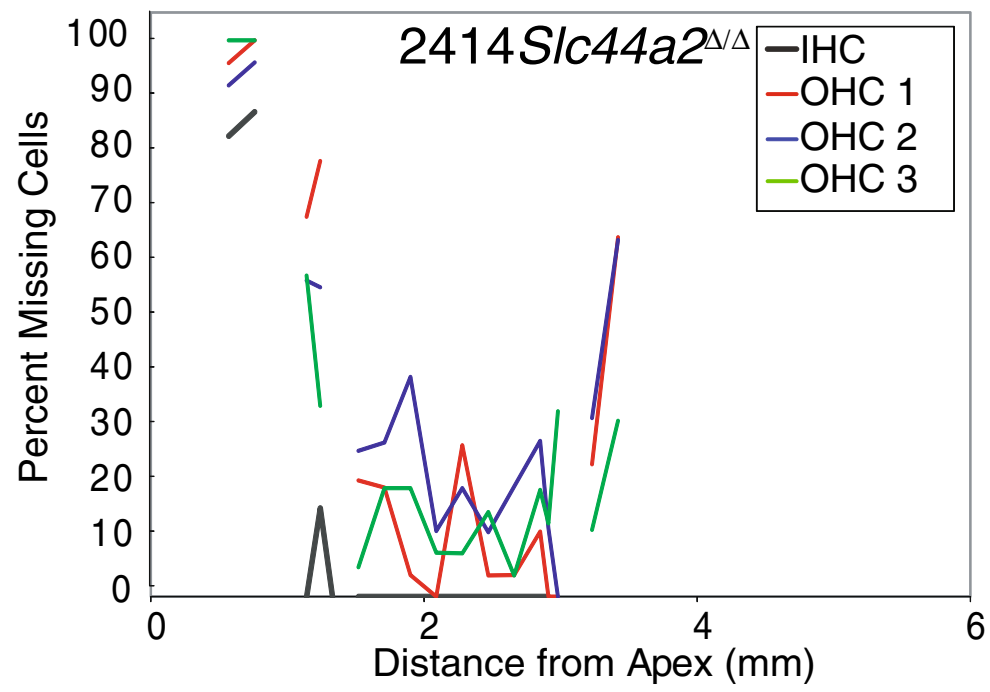

FIG. 7. Whole-mount surface preparations of the inner ear from FVB N7 F1 mice at 8 months of age. Left panels: indirect immunofluorescence (red-phalloidin and green—myosin 7a). Right panels: cytocochleograms of wild-type mouse $2416(+/+)$, heterozygous $2418\left(+/ S / c 44 a 2^{\Delta}\right)$, and knockout $2414\left(S / c 44 a 2^{\Delta / \Delta}\right)$. Top panels: +/+ mouse 2416 surface preparation and cytocochleogram display minimum loss of hair cells from apex to base. Middle panels:
$+/ S / C 44 a 2^{\Delta}$ mouse 2418 exhibits more frequent outer hair cell loss in the apex and basal turns, and cytocochleogram displays the same pattern (depicts a "U" shaped loss, a typical pattern of age-related loss/damage). Bottom panels: mouse $2414\left(S / c 44 a 2^{\Delta / \Delta}\right)$ demonstrates extensive hair cell loss in all three turns. 


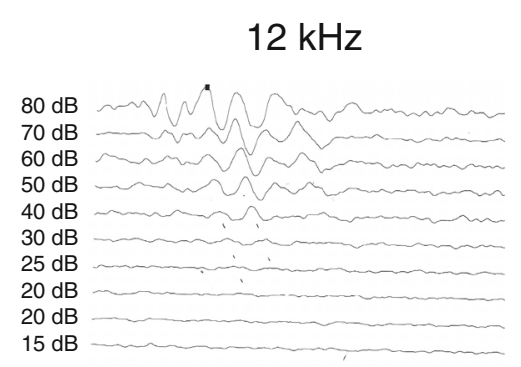

hearing threshold: $20 \mathrm{~dB}$ SPL

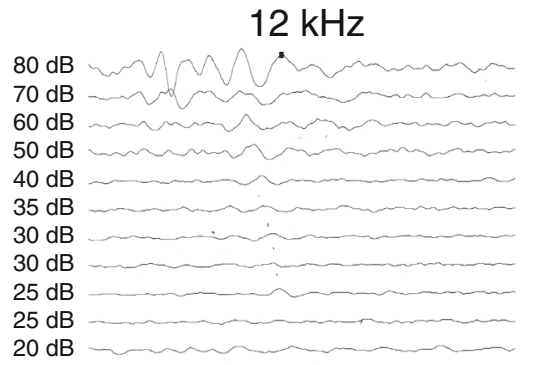

hearing threshold: $25 \mathrm{~dB}$ SPL

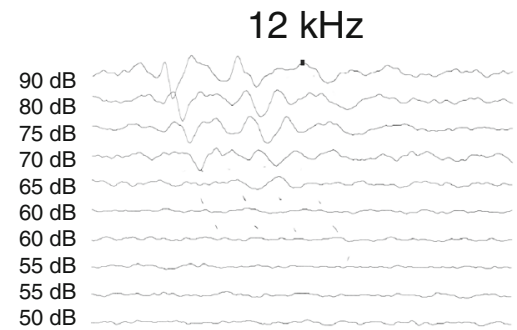

hearing threshold: $60 \mathrm{~dB}$ SPL

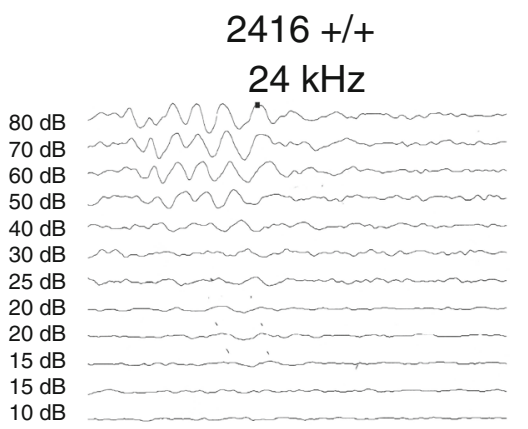

hearing threshold: $15 \mathrm{~dB}$ SPL

$2418+/ S / c 44 a 2^{4}$

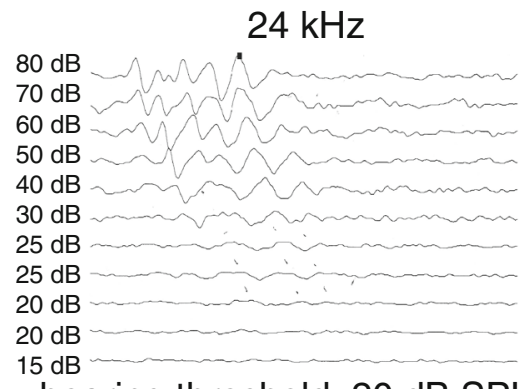

hearing threshold: $20 \mathrm{~dB}$ SPL

$2414 S / c 44 a 2^{\Delta / \Delta}$

$24 \mathrm{kHz}$

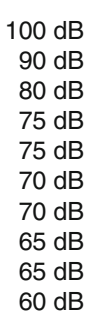

$60 \mathrm{~dB}$

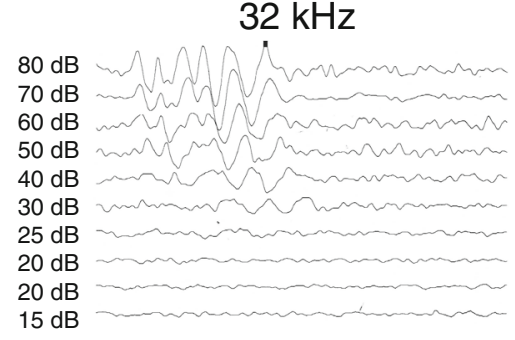

hearing threshold: $20 \mathrm{~dB}$ SPL

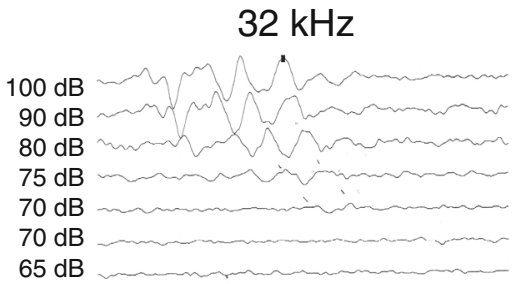

hearing threshold: $70 \mathrm{~dB}$ SPL
FIG. 8. ABR recordings from the same mice presented in Figure 7. Top row: mouse $2416(+/+)$ exhibits normal hearing at all three frequencies. Middle row: mouse $2332\left(+/ S / c 44 a 2^{\Delta}\right)$ exhibits an elevated threshold at $32 \mathrm{kHz}$ but normal hearing thresholds at 12
Immunoprecipitation of the supporting cell antigen from guinea pig inner ear extracts using KHRI-3 yielded protein bands of 68 and $72 \mathrm{kDa}$. The peptides from the trypsin-digested bands identified by tandem mass spectroscopy when compared to known proteins (Nair et al. 2004) showed homology to the newly identified CTL1 (choline transporterlike protein 1) (O'Regan et al. 2000) and identity to its putative homolog CTL2 (choline transporter-like protein 2) (Nair et al. 2004). The choline transporter-like proteins (CTL1-CTL5) were later classified as members of the superfamily of solute carrier (SLC) proteins, and CTL2 was designated SLC44A2. Recombinant CTL1 (SLC44A1) functions in choline transport in several vertebrate models (O'Regan et al. 2000; Michel and Bakovic 2012).
SLC44A2 has more homology to SLC44A4 and SLC44A5 than to SLC44A1 and SLC44A3 (Traiffort et al. 2013). However, the function of SLC44A2 remains uncertain. Using transduced $\mathrm{CHO}$ cells, we demonstrated only low-level transport of choline by the SLC44A2-P2 isoform preferentially expressed in the murine inner ear (Beyer et al. 2011), but not by the SLC44A2-P1 isoform that is preferentially expressed in human and guinea pig inner ear (Kommareddi et al. 2010). However, two groups have implicated choline transport by SLC44A2/ CTL2 in human cancer cells. Nakamura et al. observed glucocorticoid-induced expression of CTL1 and CTL2 messenger RNA (mRNA) and increased uptake of tritiated choline in the human lung cancer cell line A549. siRNA knockdown of 


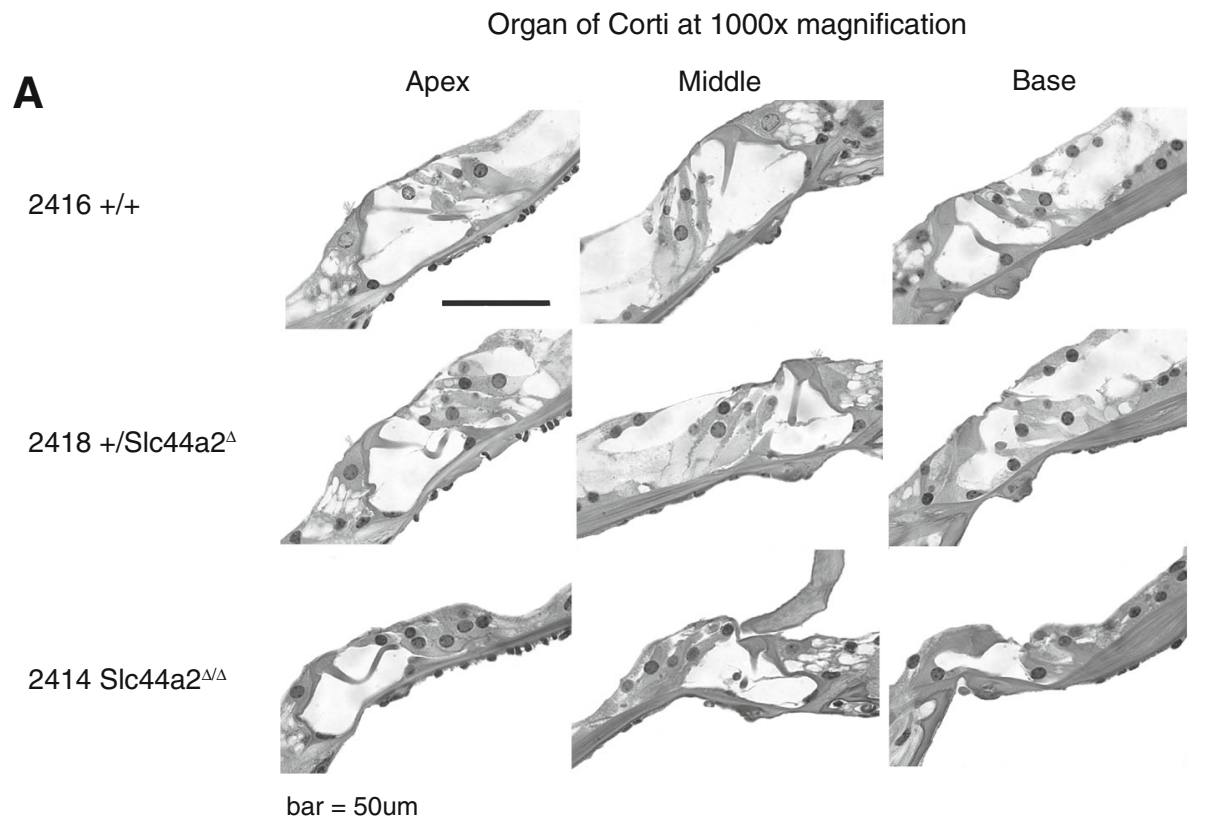

B

$2416+/+$

$2418+/{\text { SIc } 44 a 2^{\Delta}}^{\Delta}$

$2414 \operatorname{Slc}_{4} 42^{\Delta \Delta}$

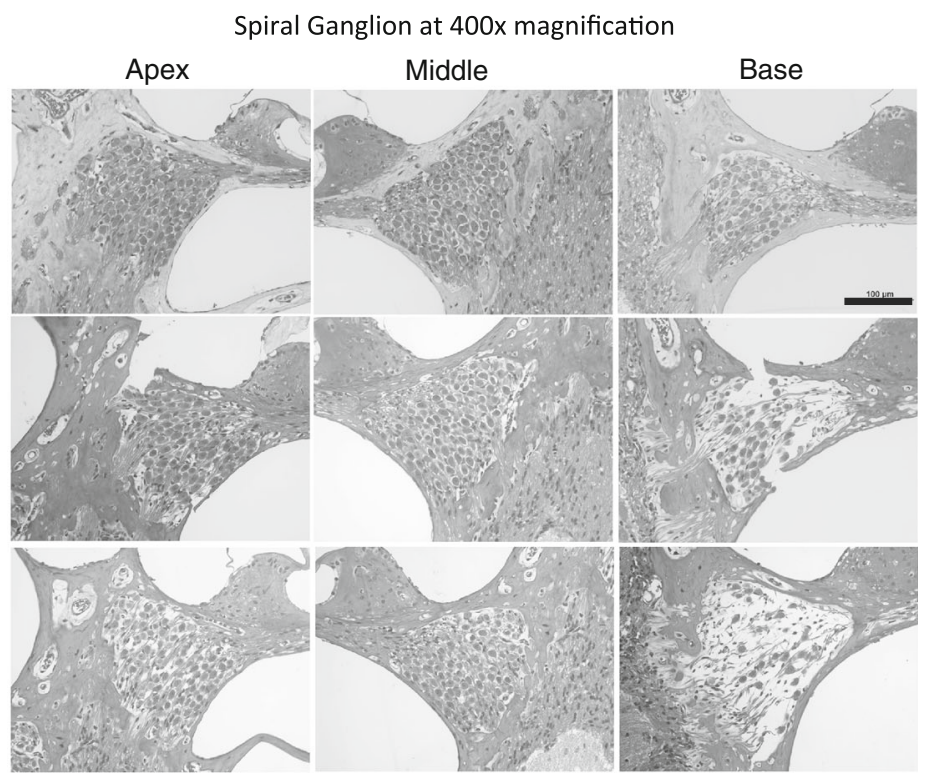

bar $=100 u m$

FIG. 9. Mid-modiolar cochlear plastic sections of the opposite ear of the same FVB N7 F1 transgenic mice shown in Figure 7. A Top panels show sections through the organ of Corti of $+/+$ mouse 2416, $+/ S / C 44 a 2^{\Delta}$ mouse 2418 , and S/C44a $2^{\Delta / \Delta}$ mouse 2414 . The organ of Corti appears relatively normal in these sections in $+/+$ and $+/$ Slc44a $2^{\Delta}$ mice. However, in the S/C44a $2^{\Delta / \Delta}$ mouse, the organ of Corti in the base appears abnormal with no detectable tunnel of Corti

CTL1 or CTL2 mRNA specifically decreased CTL1 or CTL2 expression and choline uptake (Nakamura et al. 2010). Similarly, knockdown of CTL1, CTL2, or CTL5 decreased choline transport in H82 small cell lung cancer cells (Song et al. 2013). Membership of CTL2/SLC44A2 in the solute carrier protein family strongly suggests a role in transporting a charged molecule across the membrane of inner ear and has poor representation of both inner and outer hair cells. B The lower panels depict the spiral ganglion from the same sections as shown in the upper panels. Note that in both the $+/ S / C 44 a 2^{\Delta}$ and $S / c 44 a 2^{\Delta / \Delta}$ mice, the spiral ganglion in the basal turn exhibits loss of numerous cell bodies.

supporting cells. The knockdown experiments also suggest that these members of the CTL/SLC44 family may work together to form a functional transporter system, since knockdown of any one of the three members of the family decreases choline transport in human cancer cells. This may explain why expressing SLC44A2 alone was not efficient in inducing choline transport in $\mathrm{CHO}$ cells. 


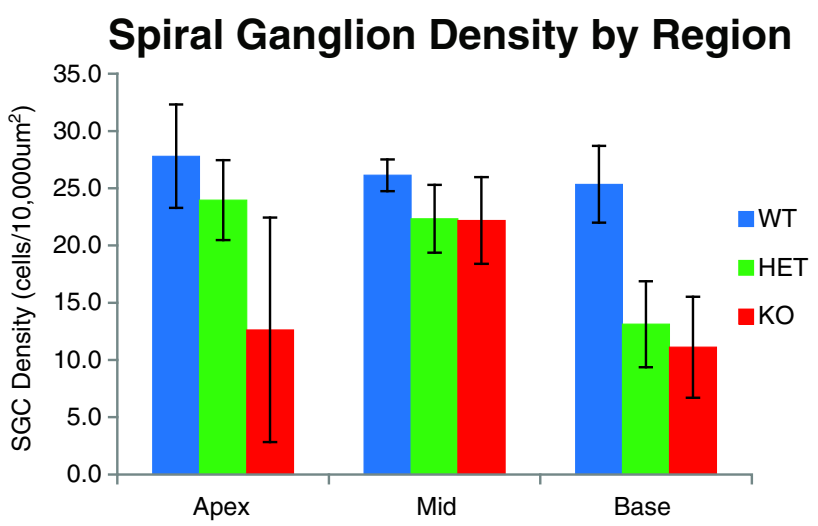

FIG. 10. Spiral ganglion cell density (cells/10,000 $\mu \mathrm{m}^{2)}$ across the apex, middle, and basal turns of the cochlea for $5+/+, 4+/ S / C 44 a 2^{\Delta,}$ and 7 S/C44a $2^{\Delta / \Delta}$ animals. SGCs were intact for $+/+$ mice at all regions. The apical and basal parts of the spiral ganglion of $S / c 44 a 2^{\Delta /}$ ${ }^{\Delta}$ mice showed extensive loss of cells, while $+/ S / c 44 a 2^{\Delta}$ mice demonstrated density loss only at the base.

SLC44A2 is strongly expressed in supporting cells in the vestibular system (Nair et al. 2004; Beyer et al. 2011) and in the developing mouse otic capsule. In our developmental study (Beyer et al. 2011), SLC44A2 was expressed in hair cells and supporting cells at embryonic days E17 and E18, but expression in hair cells declined and remained only in supporting cells by postnatal day $\mathrm{P} 1$. Therefore, this protein also may have a role in the early development of the inner ear.

In the current study, we report the effects on hearing of a targeted deletion of exons 3-10 of Slc44a2 in the mouse. We opted to delete exons 310 that encode the first and largest outer loop of the Slc44a2 molecule. The first outer loop has two Nglycosylation sites that likely contribute to SLC44A2 function, since the KHRI-3 antibody binds to the Nlinked carbohydrate, but not the protein backbone of SLC44A2 (Nair et al. 2004). Studies of human antibodies to the human neutrophil antigen HNA3a carried on the SLC44A2 molecule (Curtis et al. 2010; Greinacher et al. 2010; Bux 2011) also suggest an

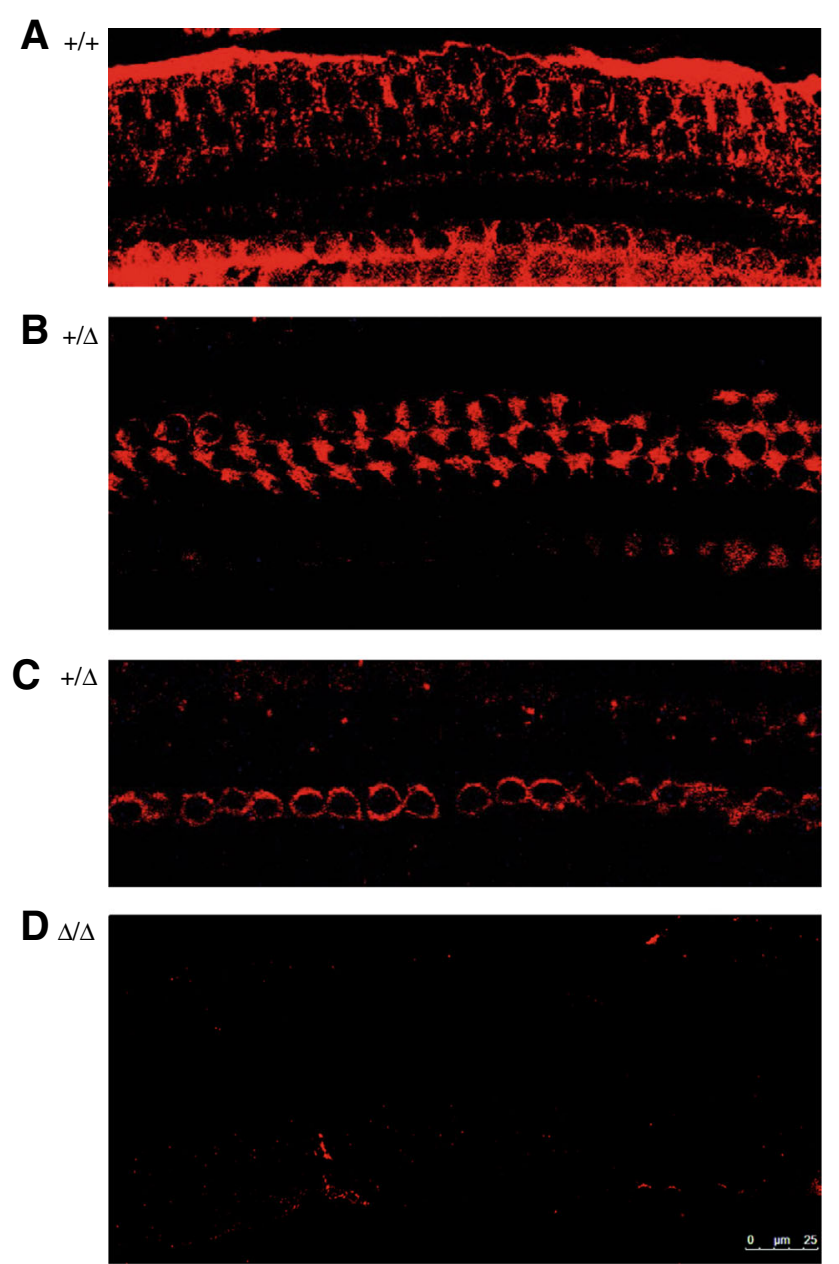

bar $=25 u m$

FIG. 11. Whole-mount surface preparations of the inner ear from FVB N7 F4 mice labeled with affinity-purified rabbit anti-SLC44A2 antibody (CTL2-NT) (red). FVB wild-type (+/+) (upper panel) and heterozygous $\left(+/ S / C 44 a 2^{\Delta}\right)($ middle panels) exhibit respectively high and moderate levels of Slc44a2 protein expression in supporting cells in the organ of Corti; Slc44a2 ${ }^{\Delta / \Delta}$ mice fail to express Slc44a2 (lower panel) in the organ of Corti.

important role for the first outer loop. SLC44A2 is strongly expressed in lung (Kommareddi et al. 2010)

TABLE 5

SGC analysis of location/genotype vs. density

\begin{tabular}{|c|c|c|c|c|c|c|c|}
\hline Source & DF & \multicolumn{2}{|c|}{ Type III SS } & Mean square & $F$ value & \multicolumn{2}{|l|}{$\mathrm{Pr}>\mathrm{F}$} \\
\hline Location & 2 & \multicolumn{2}{|c|}{438.701667} & 6.87 & 0.0026 & \multicolumn{2}{|c|}{219.350833} \\
\hline Genotype & 2 & \multicolumn{2}{|c|}{1080.297071} & 16.91 & $<0.0001$ & \multicolumn{2}{|c|}{540.148536} \\
\hline \multicolumn{4}{|c|}{ LS means: location vs. density } & \multicolumn{4}{|c|}{ LS means: genotype vs. density } \\
\hline \multicolumn{4}{|c|}{$\operatorname{Pr}>|\mathrm{t}|$ for HO: LSMean $(i)=\operatorname{LSMean}(j)$} & \multicolumn{4}{|c|}{$\operatorname{Pr}>|\mathrm{t}|$ for HO: LSMean $(i)=$ LSMean $(j)$} \\
\hline$i / j$ & Base & Mid & Apex & $i / j$ & WT & Het & $\mathrm{KO}$ \\
\hline Base & & 0.0017 & 0.108 & WT & & 0.0114 & $<0.0001$ \\
\hline Mid & 0.0017 & & 0.2456 & HET & 0.0114 & & 0.0834 \\
\hline Apex & 0.108 & 0.2456 & & $\mathrm{KO}$ & $<0.0001$ & 0.0834 & \\
\hline
\end{tabular}

Analysis of the role of cochlear location (apex, middle, base) and genotype (WT [+/+], HET, [+/S/c44aa $\left.2^{\Delta}\right], \mathrm{KO}\left[S / c 44 a 2^{\Delta / \Delta}\right]$ ) as a correlate of spiral ganglion cell density. Statistical significance defined as $p<0.05$. When comparing density vs. location, SGC density is only different between the base and middle turns ( $p=0.0017)$. For genotype vs. density, a statistically significant difference was found between WT and HET ( $p=0.0114)$ and WT and KO $(p<0.0001)$. The difference in SGC density between HET and KO mice approaches significance $(p=0.0834)$ 
and on subsets of human white blood cells, notably granulocytes (Curtis et al. 2010; Greinacher et al. 2010; Bux 2011). The HNA3a/HNA3b neutrophil antigens are defined by a polymorphism at codon 152 of the SLC44A2 gene that encodes either arginine or glutamine at this site. HNA3a antibodies arise in individuals typed as HNA3b and bind to SLC44A2 molecules that express arginine 152. Such antibodies agglutinate granulocytes and cause degranulation, indicating a key functional significance of the SLC44A2 first outer loop. Antibody binding to this molecule on granulocytes causes degranulation and release of cytokines resulting in acute lung injury (Curtis et al. 2011). Antibody binding to lung tissue itself (Kommareddi et al. 2010) may also contribute to antibody-mediated lung damage in transfusion-related lung injury (Bux 2011). Furthermore, KHRI-3 binding to SLC44A2 interferes with a supporting cell function that is essential for hair cell survival, since hair cells begin to die and hearing loss ensues after antibody binding (Nair et al. 1995, 1997, 1999).

We developed the targeted Slc44a2 $2^{\Delta}$ allele in the C57BL/6 mouse strain. Slc44a2 transcripts expressed from the $\Delta$ allele spliced out of frame from exon 2 to exon 11, resulting in a shift of reading frame and a subsequent premature stop codon. Mice homozygous for the deletion allele $\left(\operatorname{Slc} 44 a 2^{\Delta / \Delta}\right)$ lacked detectable expression of the full-length SLC44A2 protein. There was no expression of a truncated protein encoded by the aberrantly spliced $\Delta$ allele, suggesting that this mutation is likely null. After the Slc44a2 $2^{\Delta}$ allele was transferred to the FVB/NJ genetic background to remove the mutant $C d h 23^{753 A}$ allele carried by C57BL/6J, progressive high-frequency hearing loss at $32 \mathrm{kHz}$ developed as early as 4 months in the homozygous Slc $44 a 2^{\Delta / \Delta}$ mice. Progressive hearing loss also developed in these mice at 12 and $24 \mathrm{kHz}$ after 6 months of age. Hearing loss in the FVB Slc44a $2^{\Delta / \Delta}$ mice is accompanied by extensive outer hair cell loss as well as patchy inner hair cell loss and loss of spiral ganglion cells in the basal turn were found in both the Slc $44 a 2^{\Delta / \Delta}$ mice and in some $+/ S l c 44 a 2^{\Delta}$ mice, suggesting that loss of even one copy of the gene has adverse effects on inner ear homeostasis.

This study has shown the effects of Slc44a2 deletion on hearing in a knockout mouse. Further study is necessary to determine the mechanism underlying the effects of deletion of Slc44a2 on hair cell survival and hearing. SLC44A2 is strongly expressed in supporting cells (Deiter's cells, pillar cells, inner border cells, and inner phalangeal cells) directly adjacent to inner and outer hair cells, both of which are lost to various degrees in $\operatorname{Slc} 44 a 2^{\Delta / \Delta}$ mutants (Nair et al. 1997, 1999; Kommareddi et al. 2007). SLC44A2-enriched supporting cells such as inner pillar cells, inner border cells, and the third row of
Deiter's cells are LGR5 positive and can act as progenitors for hair cells after damage (Shi et al. 2013; Bramhall et al. 2014). The role of SLC44A2 in supporting cell regeneration (Mellado Lagarde et al. 2014) and supporting cell transdifferentiation into hair cells (Korrapati et al. 2013; Shi et al. 2013; Bramhall et al. 2014) is yet to be examined. Antibody binding to SLC44A2, aminoglycoside treatment, or noise exposure result in extensive outer hair cell damage with concomitant upregulation of SLC44A2 expression (Ptok et al. 1993). Scar formation and sealing of the area of hair cell loss are the natural processes of the repair of the organ of Corti by supporting cells (Raphael and Altschuler 1991; Raphael 2002; Taylor et al. 2012), and our results suggest involvement of the SLC44A2 protein in this process (Nair et al. 1999).

We observed progressive hearing loss and SGC loss in our $S l c 44 a 2^{\Delta / \Delta}$ mice. We assume that this occurs due to the ablation of normal protein function in supporting cells that maintain healthy hair cells and protect the SGCs. Cunningham's group showed the ability of supporting cells to protect hair cells through upregulation of HSP-70 protein alone (May et al. 2013). Similarly, insulin-like growth factor 1 upregulation in inner ear also protects hair cells through supporting cell signaling (Yamamoto et al. 2014). Loss of SGCs in the Slc44a2 $2^{\Delta / \Delta}$ mice and in some +/ Slc $44 a 2^{\Delta}$ mice is another consequence of this mutant gene. Abnormalities of SGC had not been observed in prior experiments with antibody-induced hearing loss and hair cell loss (Nair et al. 1995, 1997, 1999); thus, the abnormal SGC phenotype in the heterozygous and Scl44a2-knockout mice was new. SLC44A2 expression can be appreciated in the spiral ganglion (Kommareddi et al. 2007), but this has not been extensively evaluated and it is unknown if it has a direct effect in maintaining SGCs. Genetic deletion of Slc44a2 and impairment of SLC44A2 function by antibody binding to N-linked carbohydrate modifications of the mature protein both lead to damage of mature sensory cells, which do not express SLC44A2. Stankovic et al. suggested a neuregulin (NRG1)erbB2-erbB3 crosstalk in the inner ear that is essential for SGC survival. When supporting cell erbB receptor signaling is lost, SGC neuregulins (NRGs) are also lost and SGC degeneration occurs (Stankovic et al. 2004; Monzack and Cunningham 2013). It is conceivable that loss of SLC44A2 expression in the Slc44a2 ${ }^{\Delta / \Delta}$ mice could link to changes in erbB receptor and/or NRG signaling as proposed (Stankovic et al. 2004). In our previous studies, we have showed that Slc44a2 protein expression is upregulated in damaged hair cell areas, and in our Slc44a2 knockout study, absence of this protein results in progressive hearing loss and SGC loss. It can be concluded that Slc44a2 function in 
supporting cells is required for long-term hair cell survival, spiral ganglion cell survival, and overall maintenance of hearing.

\section{ACKNOWLEDGMENTS}

We acknowledge the Transgenic Animal Model Core, the DNA Sequencing Core of the University of Michigan's Biomedical Research Cores, and the Unit for Laboratory Animal Medicine and NIH NIDCD P30 DC05188, T32 DC00011, and NIDCD R01 DC003686. We are also grateful for the skilled technical assistance of Catherine Lomax and Song Kim.

Open Access This article is distributed under the terms of the Creative Commons Attribution 4.0 International License (http://creativecommons.org/licenses/by/4.0/), which permits unrestricted use, distribution, and reproduction in any medium, provided you give appropriate credit to the original author(s) and the source, provide a link to the Creative Commons license, and indicate if changes were made.

\section{REFERENCES}

Beyer La, Galano MM, Nair TS, Kommareddi PK, Sha SH, Raphael Y, CAREY TE (2011) Age-related changes in expression of CTL2/ SLC44A2 and its isoforms in the mouse inner ear. Hear Res 282:63-68

Bramhall N, Shi F, Arnold K, Hochedlinger K, Edge AS (2014) Lgr5positive supporting cells generate new hair cells in the postnatal cochlea. Stem Cell Rep 2:311-322

Bux J (2011) Antibody-mediated (immune) transfusion-related acute lung injury. Vox Sang 100:122-128

Curtis BR, Cox NJ, Sullivan MJ, Konkashbaev A, Bowens K, Hansen $\mathrm{K}$, Aster RH (2010) The neutrophil alloantigen HNA-3a (5b) is located on choline transporter-like protein 2 and appears to be encoded by an $\mathrm{R}>\mathrm{Q} 154$ amino acid substitution. Blood 115:2073-2076

Curtis BR, Sullivan MJ, Holyst MT, Szabo A, Bougie DW, Aster RH (2011) HNA-3a-specific antibodies recognize choline transporter-like protein-2 peptides containing arginine, but not glutamine at position 154. Transfusion 51:2168-2174

Disher MJ, Ramakrishnan A, Nair TS, Miller JM, Telian SA, Arts HA, Sataloff RT, Altschuler RA, Raphael Y, Carey TE (1997) Human autoantibodies and monoclonal antibody KHRI-3 bind to a phylogenetically conserved inner-ear-supporting cell antigen. Ann N Y Acad Sci 830:253-265

Greinacher A, Wesche J, Hammer E, Furll B, Volker U, Reil A, Bux J (2010) Characterization of the human neutrophil alloantigen3a. Nat Med 16:45-48

He L, Vasiliou K, Nebert DW (2009) Analysis and update of the human solute carrier (SLC) gene superfamily. Human Genom 3:195-206

Hiraoka M, Abe A, Lu Y, Yang K, Han X, Gross RW, Shayman JA (2006) Lysosomal phospholipase A2 and phospholipidosis. Mol Cell Biol 26:6139-6148

Hughes ED, Saunders TL (2011) Gene targeting in embryonic stem cells. In: Advanced protocols for animal transgenesis (S P, TL S, eds), pp 291-325. Springer, Berlin
Kommareddi PK, Nair TS, Raphael Y, Telian SA, Kim AH, Arts HA, EL-Kashlan HK, CaRey TE (2007) Cochlin isoforms and their interaction with CTL2 (SLC44A2) in the inner ear. J Assoc Res Otolaryngol 8:435-446

Kommareddi PK, Nair TS, Vallurupalli M, Telian SA, Arts HA, ELKashlan HK, Sataloff RT, Carey TE (2009) Autoantibodies to recombinant human CTL2 in autoimmune hearing loss. Laryngoscope 119:924-932

Kommareddi PK, Nair TS, Thang LV, Galano MM, Babu E, Ganapathy V, Kanazawa T, McHugh JB, Carey TE (2010) Isoforms, expression, glycosylation, and tissue distribution of CTL2/SLC44A2. Protein J 29(6):417-26

Korrapati S, Roux I, Glowatzki E, Doetzlhofer A (2013) Notch signaling limits supporting cell plasticity in the hair celldamaged early postnatal murine cochlea. PLoS One 8(8):e73276

Kranz A, Fu J, Duerschie K, Weidlich S, Naumann R, Stewart AF, Anastassiadis K (2010) An improved Flp deleter mouse in $\mathrm{C} 57 \mathrm{Bl} / 6$ based on Flpo recombinase. Genesis 48:512-520

May La, Kramarenko II, Brandon CS, Voelkel-Johnson C, Roy S, Truong K, Francis SP, Monzack EL, Lee FS, Cunningham LL (2013) Inner ear supporting cells protect hair cells by secreting HSP70. J Clin Invest 123:3577-3587

Meisler MH, Grant AE, Jones JM, Lenk GM, He F, Todd PK, Kamali M, Albin RL, Lieberman AP, Langenecker SA, McInnis MG (2013) C9ORF72 expansion in a family with bipolar disorder. Bipolar Disord 15:326-332

Mellado Lagarde MM, Wan G, Zhang L, Gigliello AR, McInnis JJ, Zhang Y, Bergles D, Zuo J, Corfas G (2014) Spontaneous regeneration of cochlear supporting cells after neonatal ablation ensures hearing in the adult mouse. Proc Natl Acad Sci U S A 111:16919-16924

Michel V, Bakovic M (2012) The ubiquitous choline transporter SLC44A1. Cent Nerv Syst Agents Med Chem 12:70-81

Miller SA, Dykes DD, Polesky HF (1988) A simple salting out procedure for extracting DNA from human nucleated cells. Nucleic Acids Res 16:1215

Monzack EL, Cunningham LL (2013) Lead roles for supporting actors: critical functions of inner ear supporting cells. Hear Res 303:20-29

Nagy A, Rossant J, Nagy R, Abramow-Newerly W, Roder JC (1993) Derivation of completely cell culture-derived mice from earlypassage embryonic stem cells. Proc Natl Acad Sci U S A 90:84248428

Nair TS, Raphael Y, Dolan DF, Parrett tJ, Perlman LS, Brahmbhatt VR, Wang Y, Hou X, Ganjei G, Nuttall AL et al (1995) Monoclonal antibody induced hearing loss. Hear Res 83:101113

Nair TS, Prieskorn DM, Miller JM, Mori A, Gray J, Carey TE (1997) In vivo binding and hearing loss after intracochlear infusion of KHRI-3 antibody. Hear Res 107:93-101

Nair TS, Prieskorn DM, Miller JM, Dolan DF, Raphael Y, Carey TE (1999) KHRI-3 monoclonal antibody-induced damage to the inner ear: antibody staining of nascent scars. Hear Res 129:5060

Nair TS, Kozma Ke, Hoefling NL, Kommareddi PK, Ueda Y, Gong TW, Lomax Mi, Lansford CD, Telian SA, Satar B, Arts HA, ELKashlan HK, Berryhill WE, Raphael Y, Carey TE (2004) Identification and characterization of choline transporter-like protein 2, an inner ear glycoprotein of 68 and $72 \mathrm{kDa}$ that is the target of antibody-induced hearing loss. J Neurosci 24:1772-1779

Nakamura T, Fujiwara R, Ishiguro N, Oyabu M, Nakanishi T, Shirasaka Y, Maeda T, Tamai I (2010) Involvement of choline transporter-like proteins, CTL1 and CTL2, in glucocorticoidinduced acceleration of phosphatidylcholine synthesis via increased choline uptake. Biol Pharm Bull 33:691-696 
Noben-Trauth K, Zheng QY, Johnson KR (2003) Association of cadherin 23 with polygenic inheritance and genetic modification of sensorineural hearing loss. Nat Genet 35:21-23

O'Regan S, Traiffort E, Ruat M, Cha N, Compaore D, Meunier FM (2000) An electric lobe suppressor for a yeast choline transport mutation belongs to a new family of transporter-like proteins. Proc Natl Acad Sci U S A 97:1835-1840

Ptok M, Carey TE, Altschuler RA (1993) Relationship of monoclonalantibody (KHRI 3 epitope) to cochlear supporting cell microvilli in the guinea-pig. Eur Arch Otorhinolaryngol 250:345-350

RAPHAEL Y (2002) Cochlear pathology, sensory cell death and regeneration. Br Med Bull 63:25-38

RApHAEl Y, Altschuler RA (1991) Scar formation after drug-induced cochlear insult. Hear Res 51:173-183

Sha SH, Kanicki A, Dootz G, Talaska AE, Halsey K, Dolan D, Altschuler R, Schacht J (2008) Age-related auditory pathology in the CBA/J mouse. Hear Res 243:87-94

SHi F, Hu L, EDGE AS (2013) Generation of hair cells in neonatal mice by beta-catenin overexpression in Lgr5-positive cochlear progenitors. Proc Natl Acad Sci U S A 110:13851-13856

Song P, Rekow SS, Singleton CA, Sekhon HS, Dissen GA, Zhou M, Campling B, Lindstrom J, Spindel ER (2013) Choline transporterlike protein 4 (CTL4) links to non-neuronal acetylcholine synthesis. J Neurochem 126:451-461
Stankovic K, Rio C, Xia AP, Sugawara M, Adams JC, Liberman MC, CORFAS G (2004) Survival of adult spiral ganglion neurons requires erbB receptor signaling in the inner ear. J Neurosci 24:8651-8661

TAYLOR RR, JAGGER DJ, Forge A (2012) Defining the cellular environment in the organ of Corti following extensive hair cell loss: a basis for future sensory cell replacement in the cochlea. PLoS One 7(1):e30577

Traiffort E, O'Regan S, Ruat M (2013) The choline transporter-like family SLC44: properties and roles in human diseases. Mol Asp Med 34:646-654

Wan G, Corfas G, Stone JS (2013) Inner ear supporting cells: rethinking the silent majority. Semin Cell Dev Biol 24:448-459

Yамамото N, Nakagawa T, Iто J (2014) Application of insulin-like growth factor-1 in the treatment of inner ear disorders. Front Pharmacol 5:208

Zajic G, Nair TS, Ptok M, Van Waes C, Altschuler RA, Schacht J, CAREY TE (1991) Monoclonal antibodies to inner ear antigens: I. Antigens expressed by supporting cells of the guinea pig cochlea. Hear Res 52:59-71

Zeitoun H, Beckman JG, Arts HA, Lansford CD, Lee DS, El-Kashlan HK, Telian SA, Denny DE, Ramakrishnan A, Nair TS, Disher MJ, SATAloff RT, Fisher SG, CAREY TE (2005) Corticosteroid response and supporting cell antibody in autoimmune hearing loss. Arch Otolaryngol Head Neck Surg 131:665-672 